IFN Working Paper No. 935, 2012

\title{
Employment Protection and Multinational Enterprises: Theory and Evidence from Micro Data
}

Pehr-Johan Norbäck, Jing-Lin Duanmu and Per Skedinger 


\title{
Employment Protection and Multinational Enterprises:
}

\section{Theory and Evidence from Micro Data}

\author{
Pehr-Johan Norbäck*, Jing-Lin Duanmu** and Per Skedinger***
}

October 23, 2012

\begin{abstract}
In this paper we show, theoretically and empirically, that stronger employment protection legislation (EPL) in a host country has important and differing effects on the various activities of multinational enterprises (MNEs). Using micro data on affiliates to Swedish multinational firms in 20 countries for the period of 1965-1998, we find that increased stringency in EPL is associated with fewer investments in new affiliates and lower employment in existing affiliates. We also find that it is mainly affiliate exports that are affected negatively by stronger EPL, while the impact on local sales is small. This is in accordance with our theoretical model, which predicts that the impact of EPL on the costs of competing firms is likely to put affiliates at a smaller disadvantage when selling for the local market than in the production for exports.
\end{abstract}

JEL Classifications F23, J8, C20

Keywords: Labor market institutions, firm heterogeneity, oligopoly, Platform-FDI, Horizontal-FDI, Micro data

\footnotetext{
\# We thank Shon Ferguson for valuable comments and Joakim Jansson, Louise Johannesson, Dina Neiman and Nina Öhrn for expert research assistance. Financial support from the Jan Wallander and Tom Hedelius Foundation is gratefully acknowledged (first and third author).

*Research Institute of Industrial Economics, Stockholm, Sweden. Email: pehr johan.norback@ifn.se. Tel: +46 (0)8 665 4522; Fax: +46 (0)8 6654599.

** School of Management, University of Surrey, United Kingdom. Email: j.duanmu@ surrey.ac.uk. Tel: +44 148368 6342; Fax: +44 1483686306.

*** Research Institute of Industrial Economics, Stockholm, Sweden. Email: per.skedinger@ifn.se. Tel: + 46(0)8 665 4553; Fax: +46 (0)8 6654599.
} 


\section{Introduction}

Many countries show an interest in attracting foreign direct investments (FDI). Potential host countries recognize that FDI can improve the productivity efficiency of the business sector. Not only do multinational firms (MNEs) pay higher wages than indigenous firms, they are also more productive and do more R\&D. Increasing globalization and volatility of employment may however also increase the demand for job security. A conflict may then arise between the host country government's ambition to protect employment and its ambition to attract FDI. In this paper, we examine how FDI is affected by the stringency of employment protection legislation (EPL) in the host country.

Investigating the relationship between EPL and FDI is challenging for a least three reasons:

First, it seems intuitive that more stringent EPL increases labor costs, since it becomes more costly to dismiss workers. This effect is reinforced if stronger protection improves the bargaining position of workers and hence increases their wage demands. However, there are also mechanisms through which stronger EPL can reduce wages. Lazear (1990) has suggested that more job security may contribute to lower wages, and possibly leave total labor costs unchanged, if employers can shift increased dismissal costs onto workers. Thus the relationship between more stringent EPL and labor costs-and hence also the relationship between EPL and FDI-is ambiguous a priori.

Second, the term FDI in itself refers to multiple decisions made by a multinational firm. These may involve investing into a new affiliate, or deciding on employment and sales in an existing affiliate, where some sales may be destined to markets outside the host country market as exports. The impact of more stringent EPL on these decisions may not be uniform.

Finally, EPL is not decided upon in isolation of other labor market policies or other host country policies.

In order to identify how more stringent EPL affects inward foreign direct investments we proceed as follows.

We first develop a three-country model with heterogeneous firms, where firms compete in an oligopolistic Cournot market. In one of the countries there is an MNE that may invest in the other two countries. If the MNE invests in one foreign country it may serve the other foreign 
country with affiliate exports. We model the impact of EPL on the firms' marginal costs in reduced form. Depending on the particular mechanism at work, more stringent EPL can increase_-or decrease_-labor costs and hence marginal costs.

For instance, if more stringent EPL in the host country increases firms' labor costs, the impact on an affiliate will depend on the increase in the unit wage cost of the affiliate relative to the average unit wage cost increase of its rivals. The average increase in rivals wage costs, in turn, depends on the destination market of affiliate sales.

When more stringent EPL in the host country increases labor costs, the affiliate's local sales may not be affected or may even increase. The reason is that a general increase in labor costs may give the MNE a strategic advantage in the host country market. This occurs as an affiliate is typically more productive than the average indigenous rival and indigenous firms dominate the local market (as trade costs limit import competition from foreign competitors). However, affiliate export sales are likely to be reduced, since indigenous rivals (which dominate in the export market) are not directly affected by EPL in the host country and only the MNE (and exporting rivals from the host country) faces higher labor costs. In general, affiliate export sales may then be more strongly affected by more stringent EPL than affiliate local sales. This will also imply that affiliate employment in export production is reduced more than employment in production for local sales. However, if more stringent EPL reduces labor costs, the impact on affiliate local sales and exports (and the corresponding employments) is reversed. The overall effect on the MNE's investment decision (i.e. whether or not to establish an affiliate) will depend on how important export production is for the profits of the affiliate.

To identify the impact of more stringent EPL on wage costs and subsequently the effect of more stringent EPL on the activities of MNEs, we proceed to examine these predictions on unique affiliate micro data on Swedish multinational firms for the period of 1965-1998. We derive estimation equations for the investment decision of establishing new affiliates (extensive margin), affiliate employment, affiliate local sales and affiliate export sales (intensive margin). To examine the impact of the stringency of EPL in the host country, we use an index developed by Allard (2005) which is available for the 20 OECD countries we consider for our period of study.

Controlling for other labor market institutions, we find that making EPL more stringent in a host country reduces both employment in the affiliate and its export sales, while having no 
effect on affiliate local sales. From the theory, these results imply that more stringent EPL increases actual or expected wage costs and that employment in both activities must decrease, albeit the effect on employment in export production is much stronger. For instance, the model predicts that a 10 percent increase in labor costs from more stringent EPL results in a 22.5 percent reduction of affiliate employment in export production, while the reduction in employment for local sales production is 10 percent.

We also find that the number of new affiliates in the host country decreases when the strictness of EPL increases, which is further evidence that stricter EPL serves to increase labor costs. In addition, we demonstrate that firm heterogeneity, with respect to size of the mother firm and volatility of output in the industry, in which the mother firm is active, attenuates the negative effect of stringent EPL for small MNEs and those with high volatility of output. Our study thus makes significant contribution to the literature by demonstrating the complex micro activities of MNEs, and consequently, their differential response to the host country's EPL. Unlike many other labor market institutions, EPL is readily affected by policy, so our results should have implications for how host countries can position their labor market policies to benefit from FDI.

We organize the rest of the paper as follows. In Section 2, we relate our paper to the literature. Our theoretical modeling is presented in Section 3, in which a number of testable hypotheses are derived. We lay out our empirical strategy in Section 4, where the data source and econometric methods are introduced and the empirical results are presented. Section 5 concludes the paper.

\section{Related literature}

A major contribution of our work is to separate the effect of more stringent EPL on the extensive margin of FDI (i.e. the investment decision into an affiliate), from the effect of more stringent EPL on various components of the intensive margin of FDI (i.e. the employment of the affiliate and the composition of sales into affiliate exports and local sales). This approach requires access to data disaggregated into the relevant observation units and dimensions, namely affiliate-level data (with information also on the parent company) disaggregated by activity. 
To the best of our knowledge, all previous econometric studies on the relationship between FDI and EPL use data that are more aggregate than ours in at least one of these respects and in most cases more aggregate in both. Examples of the latter are Benassy-Quéré, Coupet and Mayer (2007), Dewit, Görg and Montagna (2009), Görg (2005) and Gross and Ryan (2008), who all find that FDI is hampered by more stringent EPL.

Javorcik and Spatareanu (2005) and Lafontaine and Sividasan (2009) use firm-level data as we do, but do not distinguish between the various activities of MNEs. Javorcik and Spatareanu (2005) study the investment decisions of MNEs, covering 19 European countries over the period 1998-2001. They find that more stringent EPL reduces the incentive to invest, but their analysis does not examine the effect on employment. Nor do they examine the impact on the different activities of the affiliate after the investment decision is taken. Lafontaine and Sivadasan (2009) use establishment-level data on a single American fast food company investing in 43 countries over 2000-2003. They find that adjustment of employment is hampered and that entry into a country and expansion of outlets there are delayed as a consequence of more stringent EPL. While their paper also uses micro data, they do not study affiliates engaged in international trade with neighboring countries which is an essential feature in our model.

Azemar and Desbordes (2010) and Olney (2012) share our approach of disaggregating the sales activities of the MNEs, but the data used are country-level aggregates (for US firms). These papers also find an asymmetry between the effect of more stringent EPL on sales of affiliates to the local market and exports to other markets, where affiliate exports are reduced more than affiliate local sales. However, since Olney (2012) and Azemar and Desbordes (2010) use aggregate data, they cannot identify the effects of more stringent EPL on the extensive margin of FDI. This can only be done with the with affiliate level data which are used in our study.

In Azemar and Desbordes (2010) and Olney (2012), it is also suggested that the differential effect of more stringent EPL on affiliate exports and local sales arises because affiliate production for exports is more mobile than affiliate production for local sales. This suggestion rests on the effect of more stringent EPL on the extensive margin of FDI and hence cannot be explored in their data. However, there is no reason to believe that an MNE would not relocate production for local sales if labor costs become too large. Indeed, our theoretical model provides another explanation for the asymmetry which stems from the 
intensive margin of FDI. This mechanism comes from the interaction in the product market, where an increase in labor costs from EPL can give an offsetting advantage in the host country market when rivals also face increased labor costs. This will occur when the MNE is more productive than the average indigenous rival, which fits stylized facts of MNEs (see Barba-Navaretti and Venables, 2004). When exporting, however, indigenous firms in the export market do not face increased labor costs, so the MNE is put at a disadvantage, explaining the negative effect on affiliate exports. This effect, of more stringent EPL providing an MNE with an advantage in the local product market, has also been suggested in Leahy and Montagna (2000), albeit in a duopoly framework. Their paper also does not contain an empirical analysis.

\section{Theoretical framework}

In this section, we examine how more stringent EPL affects an MNE's employment, sales and investment decisions.

We first present a simple monopoly model where more stringent EPL increases the expected unit labor cost. We then discuss several extensions of this benchmark model and how these extensions qualify the effect of more stringent EPL on employment and sales.

Since labor market theory does not unambiguously sign the effect of more stringent EPL on labor costs, we turn to a model of FDI where affiliates may sell both to the local market and export to a neighboring market, and where the effect of EPL on labor costs is modeled in reduced-form. We then show how the effect of more stringent EPL on firm's labor costs can be identified from the MNE's decisions on employment, sales and investment.

\subsection{EPL and wage costs in the monopoly model}

Consider a single firm selling a product in its home country $H$, attempting to expand sales to a foreign market in Country $S$. For simplicity, assume that exports are not possible but that a foreign affiliate can be established in country $S$ to serve this market (these assumptions are relaxed in the next section). Consider the following stages: In stage 1 the firm decides whether or not to invest in a plant in country $S$ at a fixed cost, $G$. In stage 2, it hires labor at wage, $w$, and in stage 3 the output is sold in the market in country $S$. Following Haaland, Wooton and Faggio (2002), we assume that after the investment and hiring decision - but 
before the output decision - a catastrophic shock hits the firm with probability $\phi$ in which case the firm will need to close the plant and pay severance pay, $f$, per hired worker. Let $\theta$ denote the MNE's productivity and let $l(Q, \theta)$ be the labor requirement to produce output $Q$. Without the shock the MNE will use the hired labor to produce and sell the good or service earning the revenues $R(Q)=P(Q) Q$ in stage 3, where the inverse demand function is $P(Q)$. To highlight the effect of EPL we then assume that it is too costly to adjust the hired labor force if no shock occurs. This assumption greatly simplifies the exposition but does not affect results qualitatively.

The firm's expected direct profit function is then

$$
\bar{\pi}=(1-\phi)[R(Q)-w l(Q, \theta)]-\phi f l(Q, \theta)-G .
$$

To proceed, assume that demand is linear, $P(Q)=\alpha-Q$, where $P$ is the product market price, $a$ is a constant and $Q$ is, again, the firm's output. Assume constant returns to scale so that $\frac{c}{\theta}$ is the unit labor requirement. Since $R(Q)=(\alpha-Q) Q$ and $l(Q, \theta)=\frac{c}{\theta} Q$, we can rewrite the expected profit in (1) as follows:

$$
\bar{\pi}=(1-\phi)[P(Q)-\bar{c}(\theta, f)] Q-G
$$

In (2), $\bar{c}(\theta, f)$ is the expected marginal cost, where the term $\frac{\phi}{1-\phi} f$ reflects the increase in marginal cost from the risk of severance payments, $f$, in case of a closure

$$
\bar{c}(\theta, f)=\frac{w}{\theta}+\frac{\phi}{1-\phi} f w
$$

Maximizing (2) with regard to output, $Q$, the first-order condition is:

$$
P-\bar{c}(\theta, f)=Q^{*}
$$

From (4) we can now solve the firm's investment, hiring, production and sales decisions in stages 1, 2 and 3 as:

$$
Q^{*}=\frac{\alpha-\bar{c}(\theta)}{2}, \quad l^{*}=\frac{Q^{*}}{\theta}, \quad R^{*}=\left(\alpha-Q^{*}\right) Q^{*} \quad \text { and } \quad \bar{\pi}^{*}=(1-\phi)\left[Q^{*}\right]^{2}-G
$$

From (3) more stringent EPL, in the form of higher severance pay, increases the expected marginal cost, $\frac{d \bar{c}(\theta, f)}{d f}>0$. From (4) this will reduce output, $Q^{*}$, and therefore affiliate 
employment, $l^{*}$, and sales, $R^{*}$. Finally, the investment is less likely, as the expected profit, $\bar{\pi}^{*}$, is reduced.

This simple model shows that more stringent EPL will lead to lower affiliate employment and sales by increasing the expected marginal cost due to increasing expected wage costs. There are, however, other mechanisms through which stricter EPL may have a positive effect on affiliate employment and sales. Lazear (1990) has suggested that bonding may induce workers to accept a lower wage $w$ in exchange for secure employment in bad states. In our setting, bonding may then imply that the expected marginal cost, $\bar{c}(\theta, f)$, in (2) decreases when EPL becomes stricter.

It has also been suggested that stricter EPL can affect investments. For instance, Koeniger (2005) shows that if investments in capital, or technology transfers, $k$, is introduced, more stringent EPL can increase firms' incentive to invest in order to reduce labor costs. In the model above, this will benefit the MNE when paying severance payments (since under a closedown employment is smaller). By inducing investments, stronger EPL, $f$, may then reduce the marginal costs, thereby increasing sales, $R^{*}$, and potentially also employment, $l^{*}$, when the affiliate is active. ${ }^{1}$ The affiliate is however still less likely to be established since profits, $\bar{\pi}^{*}$, are reduced. ${ }^{2}$

Finally, the impact of stronger EPL on wage costs may be affected by other labor market institutions in the host country which strengthen or weaken the impact of EPL on labor costs. When turning to the empirical analysis, we will also control for other labor market institutions.

It is outside the scope of this paper to model how EPL affects labor costs in detail. To allow for different mechanisms, we will instead model the reduced-form impact of more stringent EPL on wage costs, where more stringent EPL can increase or reduce unit wage costs:

1 This can be shown by assuming the marginal cost $\bar{c}(\theta, f, k)=\frac{c-k}{\theta} w+\frac{\phi}{1-\phi} f w$ in (3) and adding a convex investment $\operatorname{cost} C(k)=\mu \frac{k^{2}}{2}$ in (2). When producing the labor demand is $l(Q, \theta, k)=\frac{c-k}{\theta} Q$. If EPL $f$ becomes more stringent, this may increase investment in $\mathrm{k}$ as the firm internalizes that with fewer employees it will need to pay less severance payments in the bad state. If the increase in investment is sufficiently large, this can reduce the marginal cost $\bar{c}(\theta, f, k)$ which will increase sales. Employment can increase if the increase in investments or technology transfer leads to a strong expansion effect in output $\mathrm{Q}$, which then compensates for the labor saving effect at a given output. A full derivation of these results is available at request.

${ }^{2}$ This can be shown using the envelope theorem. 
Definition 1: Let the unit wage cost be $\frac{\varphi(f) w}{\theta}$ where $u$ denotes other labor market institutions. Then, $\varphi_{f}^{\prime}(f)>0$ if stricter EPL increases wage costs, and $\varphi^{\prime}{ }_{f}(f)<0$ if stricter EPL decreases wage costs.

We will now proceed to show how the impact of EPL on reduced form wage costs, $\varphi^{\prime}{ }_{f}(f)$, can be identified by extending the FDI model into a framework with oligopolistic interaction and different modes of FDI.

\subsection{Oligopoly and Platform FDI}

Consider a partial equilibrium model with three countries, each containing an industry with segmented consumers. We label these countries "Home" (henceforth denoted $H$ ), "South" (henceforth denoted $S$ ) and "Rest of the world" (henceforth denoted $R$ ). In country $H$ there is a multinational enterprise (MNE), which may establish an affiliate in country $S$ and $R$. We will assume that the MNE has an existing plant in its home country $H$ which is always used to serve this market. An affiliate can serve the local market in $j \neq H$ and export to the other market. We further assume that affiliate exports only occur from country $S$ to $R$. As shown in Figure 1, this implies that the MNE can use three types of strategies. When choosing the export strategy, labeled "EXP", the MNE exports to country $S$ and $R$ from the home country, $H$. When choosing Export-platform FDI denoted "PFDI" the MNE establishes an affiliate in country $S$ and supplies the market in $R$ with exports. Finally, when establishing plants in both country $\mathrm{S}$ and country $\mathrm{R}$ these markets are served directly by the affiliates. We label this strategy as Horizontal FDI, "HFDI".

Figure 1 about here

There are indigenous firms in country $S$ and $R$ which compete in Cournot fashion with the MNE. The set of firms is $\{1,2, \ldots \theta, \ldots n\}$. Denote the number of firms producing in country $i$ and selling in country $j, n_{i j}$. The total number of firms in the world is then $n=n_{S S}+n_{R R}+$ 1 , where $n_{j j}$ is the number of firms producing for local sales in country $j=\{S, R\}$, and it is assumed that each firm always sells in its home market. The number of firms producing in country $i$ and exporting to country $j$ is $n_{i j}$ for $i \neq j$. The total number of firms selling in country $j$ is thus $n_{j}=n_{j j}+n_{i j}$, where $n_{i j}<n_{j j}$. We then assume that trade costs are 
significantly high so the number of firms exporting $n_{i j}$ is smaller than the number of firms producing and selling for the local market $n_{j j}$. To make things tractable, the total number of firms in the world, $n$, is assumed to be fixed, as well as the number of firms producing locally for the market, $n_{j j}$, and the number of firms exporting to the market, $n_{i j}$, which only depend on the MNE's strategy to serve country $j$. We discuss the implications of relaxing these assumptions when turning to the empirical analysis in Section 3.

Firms are heterogeneous since they possess firm-specific assets where the quality of these assets increases in the index $\theta$. Let the profit for a firm $\theta$ when producing in location $i$ and selling in market $j$ be:

$$
\pi_{i j}(\theta)=\left[P_{j}(\theta)-c_{i j}(k)\right] q_{i j}(\theta)-G_{i j}
$$

In equation (6), $P_{j}(\theta)$ is the price in market $j$ and $q_{i j}(\theta)$ is the output of firm $\theta$ produced in location $i$ and sold in market $j . \quad c_{i j}(\theta)$ is the marginal cost of firm $\theta$ when producing in location $i$ and selling in location $j$

$$
c_{i j}(\theta)=\frac{\varphi\left(f_{i}\right) w_{i}}{\delta(\theta)}+\tau_{i j}
$$

In equation (7), the firm-specific productivity is $\delta(\theta)$, where $\delta(\theta)$ is increasing in $\theta \cdot \frac{1}{\delta(\theta)}$ units of labor are needed to produce one unit of output with a per unit wage $\operatorname{cost} \frac{\varphi\left(f_{i}\right) w_{i}}{\delta(\theta)}$, where $\varphi\left(f_{i}\right)$ captures the reduced-form impact of EPL in the country of production, $f_{i}$, on the marginal cost as given from Definition 1. $\tau_{i j}$ is a trade-cost from separating the location of production and consumption where $\tau_{i j}>0$ for $i \neq j$ and $\tau_{i j}=0$ for $i=j$.

Consumer markets are segmented. The inverse demand in each market is $P_{j}(\theta)=\alpha_{j}(\theta)-$ $\frac{\sum_{\theta j} q_{i j}(\theta)}{\sigma_{j}}$, where the notation $\theta_{j}$ indicates that we sum over all $n_{j}$ firms active in market $j . \sigma_{j}$ denotes the market size (i.e the number of identical consumers in country $j$ ). Furthermore,

$$
\alpha_{j}(\theta)=\alpha_{j}+\gamma(\theta)
$$

is the demand intercept from consumers in country $j$ 's willingness to pay $\alpha_{j}$ while $\gamma(\theta)$ gives consumers specific willingness to pay for firm $\theta^{\prime}$ s product, where $\gamma(\theta)$ increases in the firm index $\theta$. The first-order condition from choosing output optimally is 


$$
P_{j}^{*}(\theta)-c_{i j}(k)=\frac{q_{i j}^{*}(\theta)}{\sigma_{j}}
$$

To proceed, sum over all firms active in country $j$ in equation (8) and solve for total output sold in country $j, Q_{j}^{*}=\sum_{\theta \mid j} q_{i j}^{*}(\theta)$. This gives $Q_{j}^{*}=\sigma_{j} \frac{\Lambda_{j}}{n_{j}+1}$, where $\Lambda_{j}=\sum_{\theta \mid j} \Lambda_{i j}(\theta)$ and where $\Lambda_{i j}(\theta)=\alpha_{j}(\theta)-c_{i j}(\theta)$ is the net willingness to pay for firm $\theta^{\prime}$ s product,. From (8) and (9), we then obtain optimal outputs:

$$
q_{i j}^{*}(\theta)=\sigma_{j}\left[\frac{\Lambda_{i j}(\theta)}{n_{j}+1}-\frac{\Lambda_{j}(-\theta)}{n_{j}+1}\right]
$$

where $\Lambda_{j}\left(\_\theta\right)=\sum_{-} \theta \mid j \Lambda_{i j}\left(\_\theta\right)$ sums the net willingness to pay over all competitors active in country $j$.

From (6) and (10), we can define $\pi_{i j}^{*}(\theta)=\left[P_{j}^{*}-c_{i j}(\theta)\right] q_{i j}^{*}(\theta)=\left(1 / \sigma_{j}\right)\left[q_{i j}^{*}(\theta)\right]^{2}$ as the reduced-form profit for firm $\theta$ when producing in country $i$ and selling in country $j$. It is also useful to define the reduced-form employment (or labor demand) and sales when producing in country $i$ and selling in country $j$ as $l_{i j}^{*}(\theta)=\frac{q_{i j}^{*}(\theta)}{\delta(\theta)}$ and $R_{i j}^{*}(\theta)=P_{j}^{*}(\theta) q_{i j}^{*}(\theta)$, respectively.

\subsubsection{Affiliate employment}

We will focus our attention on the MNE headquartered in country $H$. It will then be convenient to simply think of the MNE as "firm $\theta$ '. Suppose that the MNE has established an affiliate in country $S$. Suppose further that this affiliate serves as an export-platform to $R$. It then follows that affiliate employment is $l_{S}^{*}(\theta)=l_{S S}^{*}(\theta)+l_{S R}^{*}(\theta)$. Let us examine the proportional change in employment. Taking logs and differentiating in employment we obtain:

$$
\hat{l}_{S}^{*}(\theta)=\rho_{S S}(\theta) \hat{l}_{S S}^{*}(\theta)+\rho_{S R}(\theta) \hat{l}_{S R}^{*}(\theta)
$$

where a "hat" indicates a proportional change, i.e. $\hat{l}_{i j}^{*}(\theta)=\frac{d l_{i j}^{*}(\theta)}{l_{i j}^{*}(\theta)}$, and where $\rho_{i j}(\theta)$ shows the share of labor in the affiliate allocated to selling to market $j$. 
Let us now examine how the labor demand in the affiliate is affected by an increase in the stringency of EPL in country $S, d f_{S}>0$. From the marginal cost $c_{S j}(\theta)$ in (7) we obtain $d c_{S j}(\theta)=\frac{w_{S}}{\delta(\theta)} \varphi_{f}^{\prime}\left(f_{S}\right) d f_{S}$. From $l_{S j}^{*}(\theta)=\frac{q_{S j}^{*}(\theta)}{\delta(\theta)}$ and (10), we then have

$$
\hat{l}_{S j}^{*}(\theta)=\frac{\sigma_{j}}{q_{S j}^{*}(\theta)} \frac{n_{j}}{n_{j}+1}\left[\frac{\sum_{-} \theta \mid S\left(\frac{1}{\delta\left(\_\theta\right)}\right)}{n_{j}}-\frac{1}{\delta(\theta)}\right] \varphi_{f}^{\prime}\left(f_{S}\right) w_{S} d f_{S} .
$$

Equation (12) shows that the effect on affiliate employment from more stringent EPL in country $\mathrm{S}$ will depend on how the how the unit wage cost in the affiliate is affected in relation to the average impact on the unit wage cost of rivals. The term $\varphi_{f}^{\prime}\left(f_{S}\right) \frac{w_{S}}{\delta(\theta)}$ represents the change in the per unit wage cost of the affiliate in country $\mathrm{S}$, where $1 / \delta(\theta)$ is the labor productivity of the affiliate. The term $\varphi^{\prime}{ }_{f}\left(f_{S}\right)\left(\sum_{-} \theta \mid S\left(\frac{w_{S}}{\delta\left(\__{-} \theta\right)}\right)\right) / n_{j}$ is the average change in the per unit wage cost of rivals producing in country $S$ and selling in country $j$. To explore the effect on rivals in more detail, rewrite the latter expression as $\frac{\varphi_{f}^{\prime}\left(f_{S}\right) w_{S} \Sigma_{-} \theta \mid S\left(\frac{1}{\delta(-\theta)}\right)}{n_{S j}-1} \frac{\left(n_{S j}-1\right)}{n_{j}}$, where $n_{S j}$ is the total number of firms producing in country $\mathrm{S}$ and selling in country $j$ (including the affiliate). The first term then shows the average unit cost change for rivals producing in country $S$ and selling in country $j$, where $\sum_{-} \theta \mid S\left(\frac{1}{\delta\left(\_\theta\right)}\right) /\left(n_{S j}-1\right)$ is the average labor productivity of these rivals. The second term shows how important country S rivals are in the product market of country $j$, as measured by their share in the total number of firms in the market $j,\left(n_{S j}-1\right) / n_{j}$.

To proceed, suppose now that stronger EPL increases wage costs in country $S$. Formally, using Definition 1:

Assumption 1: $\varphi_{f}^{\prime}\left(f_{S}\right)>0$.

We then have the following proposition:

Proposition 1: Suppose that Assumption 1 holds, and stronger EPL in country S increases wage costs, $\varphi^{\prime}{ }_{f}\left(f_{S}\right)>0$. Suppose further that only the MNE exports from country $S$. Then, (i) affiliate employment in export production is reduced, $\hat{l}_{S R}^{*}(\theta)<0$, while $(i i)$, the effect on 
affiliate employment in local production is ambiguous, $\hat{l}_{S S}^{*}(\theta) \lesseqgtr 0$ and (iii) the total effect on affiliate employment is therefore ambiguous, $\hat{l}_{S}^{*}(\theta) \lesseqgtr 0$.

By assumption the number of rival firms exporting from country $S$ (which face higher wage costs from more stringent EPL in country $S$ ) is small in relation to the number of firms producing and selling in country $R$ (at wage costs unaffected by EPL in country S), $n_{S R}<$ $n_{R R}$. In the export market, the MNE is therefore likely to face an increase in its unit wage cost which is higher than the average rival $\varphi_{f}^{\prime}\left(f_{S}\right) \frac{w_{S}}{\delta(\theta)}>\frac{\varphi^{\prime}{ }_{f}\left(f_{S}\right) w_{S} \Sigma_{-} \theta \mid S\left(\frac{1}{\delta(-\theta)}\right)}{n_{S R^{-1}}} \frac{\left(n_{S R}-1\right)}{n_{R}}$ since most firms in the export market are indigenous firms, so that the share of country $\mathrm{S}$ rivals $\frac{n_{S R}-1}{n_{R}}$ is small. In the limit, when the MNE is the only exporter from country $S$, we have $\sum_{-} \theta \mid S\left(\frac{1}{\delta\left(\_\theta\right)}\right)=0$ (and $n_{S R}=1$ ), and the affiliate will always reduce its employment engaged in export production $\hat{l}_{S R}^{*}(\theta)<0$ from (12). This comes in part from a higher cost but also from a response from indigenous rivals in country $R$ increasing their output.

In country $S$, however, a majority of firms will face higher wage costs, $n_{S S}>n_{R S}$. This implies that the share of indigenous firm out all firms $\frac{n_{S S^{-1}}}{n_{S}}$ will be large. If the MNE is more productive than the average indigenous rival in country $S, \frac{1}{\delta(\theta)}<\sum_{-} \theta \mid S\left(\frac{1}{\delta\left(\_\theta\right)}\right) /\left(n_{S j}-\right.$ 1), the increase in per unit wage cost may then be smaller than that of the average rival $\varphi^{\prime}{ }_{f}\left(f_{S}\right) \frac{w_{S}}{\delta(\theta)}<\frac{\varphi_{f}^{\prime}\left(f_{S}\right) w_{S} \sum_{-} \theta \mid S\left(\frac{1}{\delta(-\theta)}\right)}{n_{S S^{-1}}} \frac{\left(n_{S S}-1\right)}{n_{S}}$. Affiliate employment enrolled in production for the local market will then increase $\hat{l}_{S S}^{*}(\theta)>0$ from (12) as the MNE can commit to a larger output. However, if the number of $R$ firms engaging in the competition in country $S, n_{R S}$, is large, and/or there are sufficiently many indigenous firms in country $S$ with high productivity, the MNE may encounter an increase in unit wage cost which is higher than the average increase in wage costs for the rivals. Affiliate employment in local sales would then decrease, $\hat{l}_{S S}^{*}(\theta)<0$. 


\subsubsection{Affiliate sales}

In the empirical analysis, however, we do not have information on how employment is divided in production for local sales and production for exports. In order to identify how EPL affects unit wage costs $\varphi^{\prime}{ }_{f}\left(f_{S}\right)$ and hence how more stringent EPL affects employment in these activities, it will be useful to explore how EPL affects sales flows.

From the demand for labor, output is $q_{S j}^{*}(\theta)=\delta(\theta) l_{S j}^{*}(\theta)$. Taking logs of affiliate sales, that is, $R_{S j}^{*}(\theta)=P_{j}^{*}(\theta) q_{S j}^{*}(\theta)$ and differentiating, we obtain:

$$
\hat{R}_{S j}^{*}(\theta)=\hat{P}_{j}^{*}(\theta)+\hat{l}_{S j}^{*}(\theta)
$$

So, the effect on affiliate sales in country $j$ is the sum of how stronger EPL in country $S$ affects the market price in country $j$ and affiliate employment in country $S$. It is then useful to derive the change in product market price in market $j$ when firms' marginal cost for production in country $S$ changes:

$$
\hat{P}_{j}^{*}(\theta)=\frac{\sigma_{j}}{q_{S j}^{*}(k)+\sigma_{j} c_{S j}(\theta)} \frac{n_{j}}{n_{j}+1}\left[\frac{\sum_{-} \theta \mid S d c_{S j}\left(\_\theta\right)}{n_{j}}+d c_{S j}(\theta)\right]
$$

Using the fact that $d c_{S j}(\theta)=\frac{w_{S}}{\theta} \varphi^{\prime}\left(f_{S}\right) d f_{S}$ we then have the following result:

$$
\hat{R}_{S j}^{*}(\theta)=\eta_{S j}(\theta)\left[\frac{\sum_{-} \theta \mid S\left(\frac{w_{S}}{\delta(-\theta)}\right)}{n_{j}} \frac{\varsigma_{S j}(\theta)}{\eta_{S j}(\theta)}-\frac{w_{S}}{\delta(\theta)}\right] \frac{n_{j} \sigma_{j}}{n_{j}+1} \varphi^{\prime}{ }_{f}\left(f_{S}\right) d f_{S}, \quad j=\{S, R\}
$$

where $S_{S j}(\theta)=\left(\frac{1}{q_{S j}^{*}(\theta)}+\frac{1}{q_{S j}^{*}(\theta)+\sigma_{j} c_{S j}(\theta)}\right) \quad$ and $\quad \eta_{S j}(\theta)=\left(\frac{1}{q_{S j}^{*}(\theta)}-\frac{1}{n_{j}\left[q_{S j}^{*}(\theta)+\sigma_{j} c_{S j}(\theta)\right]}\right) \quad$ and $\varsigma_{S j}(\theta) / \eta_{S j}(\theta)>1$. Thus, we again find that the effect on affiliate sales, when more stringent EPL increases wage costs, depends how much affiliate wage costs increase in relation to the average effect on competitors. Since $\varsigma_{S j}(\theta) / \eta_{S j}(\theta)>1$, it follows from (12) and (15) that the effect on sales is even more sensitive to the effect of EPL on rival firms than employment. We will make use of equation (15) below when identifying the effect of EPL on the different types of employment in Proposition 1 in the data. 


\subsubsection{Investment}

Let us finally examine the MNE's investment decision. Assuming that there is a fixed cost, $G$, of investing in a new plant in country $S$, the total profit in the export platform strategy (PFDI) is:

$$
\Pi^{P F D I}(\theta)=\pi_{H H}^{*}(\theta)+\pi_{S S}^{*}(\theta)+\pi_{S R}^{*}(\theta)-G
$$

If the MNE chooses "Horizontal FDI", it will invest in a plant in both country $S$ and $R$. This gives the total profit.

$$
\Pi^{H F D I}(\theta)=\pi_{H H}^{*}(\theta)+\pi_{S S}^{*}(\theta)+\pi_{R R}^{*}(k)-2 G
$$

The MNE may also choose to export to $R$ and $S$ from country $H$. This gives the profit:

$$
\Pi^{E X P}(\theta)=\pi_{H H}^{*}(\theta)+\pi_{H S}^{*}(\theta)+\pi_{H R}^{*}(\theta)
$$

Note that exporting (EXP) gives the lowest fixed costs, followed by Platform FDI (PFDI). Horizontal FDI (HFDI) has the highest fixed costs. As usual, the advantage of Horizontal FDI is increased market access by avoiding trade costs, $\tau_{i j}>0$ for $i \neq j$.

The MNE will choose the strategy $h \in\{E X P, P F D I, H F D I\}$ which maximizes the total profit, i.e. $h^{*}(\theta)=\operatorname{argmax}: \Pi^{h}(\theta)$. To proceed, we use the following assumption.

Assumption 2: Trade costs $\tau_{i j}$ are sufficiently high so that $\frac{d\left(\Pi^{H F D I}(\theta)\right)}{d \theta}>\frac{d\left(\Pi^{P F D I}(\theta)\right)}{d \theta}>$ $\frac{d\left(\Pi^{E X P}(\theta)\right)}{d \theta}$ holds.

With sufficiently high trade costs we then obtain the well-known result from heterogeneous firm models of FDI (see Helpman, 2006, for an overview), that firms with more productive firm-specific assets benefit the most from Horizontal FDI. The reason is that trade costs are then completely avoided and a larger sales volume benefits from a lower marginal cost or a higher willingness to pay. By the same logic, Platform FDI generate a larger profit increase than exports sales from having more productive assets, as the latter face trade costs in both market $\mathrm{R}$ and $\mathrm{S}$, while the former only face trade costs in market $\mathrm{R}$.

To proceed, define cut-offs $\Pi^{E X P}\left(\theta^{P F D I}\right)=\Pi^{P F D I}\left(\theta^{P F D I}\right)$ and $\Pi^{P F D I}\left(\theta^{H F D I}\right)=$ $\Pi^{H F D I}\left(\theta^{H F D I}\right)$. From (16)-(18), we note that export production has the lowest fixed costs while Horizontal FDI has the highest fixed cost. We then have the following Lemma. 
Lemma 1: From Assumption 2, the MNE chooses exporting for $\theta \in\left[\theta_{\text {min }}, \theta^{P F D I}\right)$, Platform FDI when $\theta \in\left[\theta^{P F D I}, \theta^{H F D I}\right)$ and Horizontal FDI when $\theta>\theta^{H F D I}$.

Thus Lemma 1 implies that $\theta^{P F D I}<\theta^{H F D I}$, so that the cut-off level of the quality of the MNE's firm-specific assets at which FDI occurs is the one for Platform FDI. This is also consistent with the data on Swedish MNE that we use below, where most affiliates do export and affiliates which only serve the local market are rare.

We can then state the following proposition:

Proposition 2: Suppose that Assumption 1 and 2 hold (so that more stringent EPL in country $S$ leads to increased unit wage costs,$\varphi^{\prime}{ }_{f}\left(f_{S}\right)>0$. Then, when EPL in country $S$ becomes sufficiently strong, the MNE will switch from Platform FDI to exporting to country S.

To prove the proposition, totally differentiate $\Pi^{E X P}\left(\theta^{P F D I}\right)=\Pi^{P F D I}\left(\theta^{P F D I}\right)$ to get:

$$
\frac{d \theta^{P F D I}}{d f_{S}}=-\frac{\frac{d\left(\Pi^{E X P}(\theta)-\Pi^{P F D I}(\theta)\right)}{d f_{S}}}{\frac{d\left(\Pi^{E X P}(\theta)-\Pi^{P F D I}(\theta)\right)}{d \theta}}>0
$$

In equation (19), $\frac{d\left(\Pi^{E X P}(\theta)-\Pi^{P F D I}(\theta)\right)}{d \theta}<0$ holds from Assumption 2. Moreover, since production costs in country $H$ are not affected by the more stringent EPL in country $S$, whereas country $S$ production face higher costs, it follows directly that

$$
\frac{d\left(\Pi^{E X P}(\theta)-\Pi^{P F D I}(\theta)\right)}{d f_{S}}=\underbrace{\frac{d \pi_{H R}^{*}(\theta)}{d f_{S}}-\frac{d \pi_{S R}^{*}(\theta)}{d f_{S}}}_{(+)}+\underbrace{\frac{d \pi_{H S}^{*}(\theta)}{d f_{S}}-\frac{d \pi_{S S}^{*}(\theta)}{d f_{S}}}_{(+)}>0
$$

Equation (19) implies that increasing the strictness of EPL must increase the cut-off $\theta^{P F D I}$, so that a higher quality $\theta$ is required to invest in an affiliate in country $S$. Therefore, when the strictness of EPL increases it becomes less likely that the MNE will invest into an affiliate in country $S$. We now turn to the empirical analysis. 


\section{Econometric analysis}

Our purpose is to estimate the effect of more stringent EPL on FDI in terms of affiliate employment, affiliate local sales, affiliate export sales and the decision to invest in an affiliate. To derive an estimation equation, consider affiliate employment, $l_{S}^{*}(\theta)=l_{S S}^{*}(\theta)+$ $l_{S R}^{*}(\theta)$. Using a first-order Taylor expansion in the exogenous variables in the model, we obtain $^{3}$

$$
\begin{aligned}
& \ln l_{S}^{*}(\theta)=\beta_{0}+\beta_{f_{S}} \ln f_{S}+\beta_{\delta} \ln \delta(\theta)+\beta_{\gamma} \ln \gamma(\theta)+\beta_{w_{S}} \ln w_{S}+\beta_{\sigma_{S}} \ln \sigma_{S} \\
& +\beta_{\alpha_{S}} \ln \alpha_{S}+\beta_{n_{S}} \ln n_{S}+\beta_{w_{R}} \ln w_{R}+\beta_{\sigma_{R}} \ln \sigma_{R}+\beta_{a_{R}} \ln \alpha_{R} \\
& +\beta_{n_{R}} \ln n_{R}+\beta_{\tau_{H S}} \ln \tau_{H S}+\beta_{\tau_{R S}} \ln \tau_{R S}+\beta_{\tau_{S R}} \ln \tau_{S R}+\beta_{f_{R}} \ln f_{R}+\varepsilon
\end{aligned}
$$

and where we have added $\varepsilon$ as the usual error term.

We will also estimate (21) replacing the dependent variable $l_{S}^{*}(\theta)$ with affiliate local sales, $R_{S S}^{*}(\theta)$, and affiliate export sales, $R_{S R}^{*}(\theta)$. We discuss restrictions that follow from the theory below. To estimate the investment decision, we substitute the dependent variable in (20) with the binary variable $F D I_{S}^{*}(\theta)=1$ if $\max \left\{\Pi^{H F D I}(\theta), \Pi^{P F D I}(\theta)\right\}>\Pi^{E X P}(\theta) .^{4}$

\subsection{Dependent variables}

Let us now discuss the data used for estimating (21). To measure the dependent variables we use data from the Research Institute of Industrial Economics (IFN) which has conducted eight surveys of the foreign activities of Swedish multinational firms in the years 1965, 1970, $1974,1978,1986,1994$, and $1998 .^{5}$ The population consists of firms meeting the following criteria (i) the firm's main activity should be within the manufacturing sector, (ii) the total

3 A Taylor-expansion of the $\log$ of employment, $\log l_{S}^{*}(x \mid \theta)$, gives (omitting $\left.\theta\right), \log l_{S}^{*}=\log l_{S}^{*}(\bar{x})+\frac{\frac{d l_{S}^{*}(\bar{x})}{d x}}{l_{S}^{*}(\bar{x})}(x-$ $\bar{x})$. Using the approximation $\ln \left(\frac{x}{\bar{x}}\right) \approx \frac{x-\bar{x}}{\bar{x}}$, the former expression can be re-written as $\log l_{S}^{*}=\log l_{S}^{*}(\bar{x})+$ $\frac{\frac{d l_{S}^{*}(\bar{x})}{d x}}{l_{S}^{*}(\bar{x})} \bar{x} \ln \left(\frac{x}{\bar{x}}\right)$. It then follows that a regression coefficient in equation (21) is $\beta_{x}=\frac{\frac{d l_{S}^{*}(\bar{x})}{d x}}{l_{S}^{*}(\bar{x})} \bar{x}=\hat{l}_{S}^{*}(\bar{x}) \frac{\bar{x}}{d x}=$ $E l_{x} l_{S}^{*}(\bar{x})$.

${ }^{4}$ Equation (21) can be then be derived by assuming a statistical distribution over $\theta$.

${ }^{5}$ These data have been used in earlier studies, such as Norbäck (2001), Braconier, Norbäck and Urban (2005a, 2005b), Davies, Tekin-Koru and Norbäck (2009), Hakkala, Norbäck and Svaleryd (2008) and Bertrand et al. (2012). See also Swedenborg (1979) for an early analysis of these data. 
number of employees should be at least 50, and (iii) the firm should have at least one producing affiliate abroad and the domicile is located in Sweden. The surveys cover almost all Swedish multinational firms with these characteristics in the manufacturing sector. We will only use survey data for the OECD countries as we are limited to countries for which there are EPL data available. This omission may be less serious considering the fact that the OECD countries account for the vast majority of foreign employment in Swedish MNEs.

The Swedish parent firms provide information on variables such as their size in terms of employment, sales, R\&D and the composition of these activities in Sweden and abroad. Firms then submit surveys to all their producing affiliates which provide data on employment, intra-firm trade, affiliate R\&D and give detailed industry classification.

We will measure affiliate employment $\left(l_{S}^{*}(\theta)\right)$ from the variable employment $_{a z \tau}$, which gives the $\operatorname{logged}$ employment of affiliate $a$ owned by firm $z$ in time $t$. Figure 2 shows the development of the mean of employment ${ }_{a z \tau}$ calculated for each country in each survey year. Average employment is at relatively high levels in Belgium, France, Germany, Italy and Portugal, while some small countries like Norway and Switzerland have attracted less FDI in terms of employment. The fitted trends reveal that there is large variation in affiliate employment across countries over time. Upward trends are discernible for Greece, Ireland, Italy, Spain and the United States, while the opposite trends can be noted for Australia, Finland, France, Japan and New Zealand.

As noted above, we do not have employment information relating to the activities of firms. In order to examine if the effect of more stringent EPL on employment differs depending where output is sold, we will make use of the information on sales flows. To obtain affiliate local sales $\left(R_{S S}^{*}(\theta)\right)$ and affiliate exports to other countries than Sweden $\left(R_{S R}^{*}(\theta)\right)$, we use the information on intra-firm trade to calculate the variables local_sales $a z \tau$ and export_third $_{a z \tau}$ which are measures the log value in millions of Swedish kronor (SEK). For each affiliate, local sales are computed as total sales minus total exports. Export to third countries is then calculated as total exports minus exports to Sweden.

Figure 3 presents the average of our affiliate local sales and affiliate exports to third countries for each OECD country over time. In general, both variables are trended upward. In some countries, like Canada, Finland, France, Germany, Italy and the United Kingdom, the 
two variables also follow each other closely. While affiliate local sales is larger in the 1960s and 1970s, export sales to third markets catch up with local sales over the years and in the 1990s export sales are on the same or even higher level. This pattern is consistent with the globalization process. We should finally note that affiliate local sales and affiliate exports to countries other than Sweden make up the lion's share of affiliate total sales. Only about 7 percent of affiliate sales are re-exported to Sweden which justifies the set-up in the theory where such "Vertical FDI" is omitted.

To measure the investment variable $F D I_{S}^{*}(\theta)$ we use the variable Invest $_{z t}$, which is a measure of the number of investments in new affiliates the parent firm $z$ has made in a host country, in a period beginning two years before the survey and ending two years after the survey in year $t$. Since this variable is a count variable we then estimate (21) by means of a negative binomial regression model. We now turn to a discussion of the explanatory variables.

\subsection{Independent variables}

\subsubsection{Measuring labor regulations}

To measure the stringency of EPL $\left(\ln f_{S}\right)$ we use the EPL index developed by Allard (2005). This index, labeled $E P L_{j t}$ where $j$ indicates the host country, is given in a scale from 0 to 6 where a higher number indicates higher stringency. Since the index is discrete we do not use it in logs. The Allard index is preferable since it is available for a sufficiently long period to cover the long time span in our data and is defined consistently across countries. Allard extended the OECD (2004) index for specific countries, covering the period 1998-2003, from 1950 to 2003. This index has the additional advantage of being comprehensive, covering legislation regarding regular employment, temporary employment and collective dismissals. Unlike the OECD index, however, Allard's index excludes two minor components of EPL, namely "delay to start a notice" and "compensation for unfair dismissal". Alternative EPL indices, with a similarly long time spans, are developed by Blanchard and Wolfers (2000) and Belot and van Ours (2004). Both indices have shortcomings for our purposes. The index of Blanchard and Wolfers (2000) links together two periods of time covering completely 
different aspects of EPL, partially from Lazear's (1990) earlier data regarding notification times and severance pay and partially from the OECD's later more comprehensive index (see Howell et al., 2007, for a discussion). Belot and van Ours (2004) have launched an index that is less comprehensive than the one developed by Allard and OECD and it is not entirely clear how the index has been constructed. Our preferred EPL index in the estimations is thus Allard's. Unfortunately, this index does not include the non-OECD countries in our MNE database and it does not distinguish between regulations for regular and temporary contracts, but this is a drawback that the index shares with both alternatives mentioned above. ${ }^{6}$

Figure 4 shows the development of Allard's EPL index in the 20 OECD host countries that we consider in this empirical analysis. Not only does the stringency of EPL vary greatly across countries, there is also considerable variation over time within many countries, thanks to the long observation period. Overall, EPL is more stringent in Southern Europe - Greece, Italy, Portugal and Spain - than in Anglo-Saxon countries - Australia, Canada, Ireland, United Kingdom and the United States. In the majority of countries there is an upward trend in EPL stringency, but some countries, notably Germany, Italy, Portugal and Spain, exhibit inverse U-shapes, with declining stringency toward the end of the period.

Definition 1 states the effect of more stringent EPL on firms' unit wage costs in reducedform, $\varphi\left(f_{S},\right) w_{S}$. More stringent EPL has a direct effect on wage costs but wage costs may be affected by other labor market institutions. To isolate the effect of EPL on wage costs from other labor market institutions we use variables taken from the Nickell database (Nickell, 2006): union coverage and union density, both in percentage terms, an index bargaining centralization, ranging from 1 to 3 , and gross replacement rates in unemployment insurance, as a percentage of average earnings before tax (all variables originating from the OECD). From Nickell's database (2006) we have also included an index for intellectual property rights (originating from Ginarte and Park, 1997).

We also apply a "difference in difference" approach. The effects of EPL may be more binding in industries with relatively large volatility of output (Bassanini, Nunziata and Venn, 2009). We therefore experiment with a dummy of an industry-specific measure of the

\footnotetext{
${ }^{6}$ Regulation for regular employment reflects more closely our specification of EPL as severance pay in the theoretical section, but a case could be made that regulation for temporary work also affects the per unit wage costs for firms.
} 
volatility of sales/output (above median volatility), interacted with the EPL index, to examine whether MNEs in certain industries are more prone to adjust their activities in response to changes in EPL.

A similar difference in difference approach is also applied to the size of firms. A dummy for large firms (above median size in terms of sales in the two digit industry in which the firm belongs) is included. On the one hand, large firms may be able to spread any fixed costs of EPL over a large number of employees and may thus be less sensitive to the cost-increasing effects of EPL than smaller firms. From the theory section the competitiveness of MNE may increase if all firms receive higher wage costs, given that the MNE belongs to the most productive firms in the market. On the other hand, large firms may be more footloose than small firms, suggesting that the former are more inclined to reduce employment in response to increasing stringency of EPL.

To account for the wage level for comparable workers in the host country, we make use of a series on the wage costs for a toolmaker, collected by the Swiss bank UBS, $w_{S}$. We also use a variable, "Regulation impact", to capture the knock-on cost of regulation in nonmanufacturing industries, which act as inputs in manufacturing industries, from OECD. OECD studies indicate that industries where regulation costs are high tend to have stronger labor market imperfections.

All our specifications include country and year fixed effects as well as firm-fixed effects or affiliate-industry effects. The latter are "dynamic" in the sense that they capture how an affiliate change product lines over time and are fairly detailed (down the 5 digit level). Thus, we will use the variation in EPL over time in the host countries to examine the impact on FDI as captured by affiliate local sales, affiliate export sales and the decision to invest. To further isolate the effect of EPL we also apply country-specific trends since there might be time varying concomitant reforms which are correlated with EPL that drive our results.

Finally, endogeneity may be a potential problem. Host countries may, for example, reduce the stringency of EPL to attract foreign investment. This is unlikely to hold for Swedish firms given Sweden's small size in the world economy. As a check for robustness in this respect, we will try estimations in which countries with the lowest GDP per capita are excluded. We assume that any tendencies to adjust EPL in response to MNE activity will be stronger in countries that are relatively more dependent on FDI. 


\subsubsection{Other control variables}

To control for firm heterogeneity in firm-specific assets $(\theta)$, we first use the size of the parent firm $z$ in the survey year $t$ as measured by the $\log$ of (world-wide) total sales, firm_size $e_{z t}$, and the parent firm's R\&D intensity as measured by the log of R\&D expenditures divided by total sales, $r d_{-} i n t_{z t}$. While we do not have information on how firms divide R\&D into process- and product innovation, firm size should be more closely related to product heterogeneity in (7) in terms of the firm-specific consumer willingness to pay $(\ln \delta(\theta))$ while $\mathrm{R} \& \mathrm{D}$ intensity should control for firm-specific productivity in (8) (labeled $\ln \gamma(\theta)$ ). To further control for firm-heterogeneity, we add the parent firm's experience in the host country, Experience $_{z t}$, defined as a dummy indicating whether the parent company previously had an affiliate in the host country. We also control for heterogeneity between affiliates and add the age of an affiliate, $A g e_{a z t}$ as well as a dummy variable indicating whether this affiliate was started as a sales affiliate, Sales_af $f_{a z t}$.

To control for host country market size, $\sigma_{S}$, we use the log of real GDP of the host country, $r g d p_{j t}$, taken from the World Bank. As a measure of the country-specific demand intercept $\left(\alpha_{S}\right)$, we use real GDP per capita, $r g d p_{-} c a p_{j t}$, again taken from the World Bank. $r g d p_{-} c a p_{j t}$ to control for $R$ 's demand, $\sigma_{R}$, we compute a distance weighted real GDP for all countries other than country $j$, including non-OECD countries, market_potential ${ }_{j t}$, following Harris (1954). ${ }^{7}$ For other unobserved country characteristics, we use country fixed effects. We also control for year fixed effects and industry or firm-fixed effects.

A problem is that we cannot measure the level of competition $\left(n_{S}\right.$ and $\left.n_{R}\right)$ in the host country (Country $S$ ) and the rest of the world (Country $R$ ). While industry-fixed effects will account for differences in competition between industries, these do not control for changes in competition in countries over time. However, relaxing the assumption of a fixed number of firms (in total and in exporting) in the theory, it follows that the demand variables, $r g d p_{j t}$, $r g d p_{-}{ }_{c a p}$ and market_potential ${ }_{j t}$, will also control for the within-country level of competition, as entry will be driven by these demand factors. This of course generates an

\footnotetext{
${ }^{7}$ We also computed distance weighted real GDP per capita to control for demand and wage in $R$. We do not include them here for the lack of space.
} 
ambiguity in the expected signs of these variables as they will capture both demand and competition effects. ${ }^{8}$

Finally, to control for trade costs, $\tau_{i j}$, we use the openness of the host country defined as the ratio of exports plus imports to nominal GDP. We also use a set of dynamic dummy variables for host country membership in EU and NAFTA, respectively. These will, to some extent, pick up variation in trade cost but will also control for omitted characteristics associated with membership. We also calculate a distance-weighted EPL indexes in neighboring countries and examine their impact on affiliate employment as the theory suggest that EPL in neighboring countries, $f_{R}$, should affect affiliate employment (since EPL in country R will affect the marginal cost of rivals producing in country $\mathrm{R}$ ). Table 1 presents summary statistics for the variables in the empirical analysis.

\subsection{Results}

\subsubsection{Affiliate employment}

Table 2 reports results for the log of the number of employees of the affiliate in the host country (employment $t_{a z t}$ ) as the dependent variable. We start with a baseline specification in column 1, with year and country fixed effects and then add firm and industry fixed effects, in columns 2 and 3, respectively. The coefficients of the EPL index $E P L_{j t}$ are negative, significant and fairly robust across specifications, indicating a deterring effect of stronger EPL on the employment level of Swedish affiliates. These results are consistent with Proposition 1 where more stringent EPL increases wage costs $\varphi_{f}^{\prime}\left(f_{S}\right)>0$ which reduce the total employment in production for the local market and exports, with $\beta_{f_{S}}<0$ in (21). The estimates are in the region -0.12 to -0.18 , suggesting that an increase in the EPL index by one unit decreases affiliate employment by 12 to 18 percent. $^{9}$

\footnotetext{
${ }^{8}$ For instance, one can show that $\beta_{\sigma_{S}}>0$ and that $\beta_{n_{S}}<0$ holds in (21).

${ }^{9}$ Note that the affiliate employment is in log form while the EPL index is a discrete index. Then, calculating the percentage change we have that, $\hat{l}_{S}^{*}(\theta)=\frac{\Delta l_{S}^{*}(\theta)}{l_{S}^{*}(\theta)}=e^{\hat{\beta}_{f}}-1$, where $\Delta l_{S}^{*}(\theta)$ is the change in employment, $l_{S}^{*}(\theta)$ is the level of employment and $\widehat{\beta}_{f_{S}}$ is the estimated coefficient.
} 
Most of the results for the firm-specific variables also yield significant results. For example, employment increases consistently in parent size, with previous experience and in the age of the affiliate. Parent R\&D intensity comes out with a negative sign in the base estimation but loses significance in the fixed-effects specifications ${ }^{10}$. Inasmuch as R\&D intensity captures process innovation, it can be shown in the Cournot model that the labor savings from higher productivity can dominate the increase in labor demand from increased sales, consistent with $\beta_{\gamma}<0$ in (21). The positive significant effect of parent size on affiliate employment would be consistent with firm-specific assets increasing consumers' willingness to pay, with $\beta_{\delta}>0$ in $(21)$.

Membership in the EU or NAFTA is associated with more employment in the affiliates. We do not get much mileage out of the macroeconomic variables - the coefficients are never significant. As noted above, an explanation for this may be that these variables capture both demand and competition effects. We have chosen to cluster the standard errors on countries in all our tables. We also experimented with clustering on affiliates and industries (at the 2-5 digit level), resulting in only small changes in inference. All three models in Table 2 attain adequate model fitness with reasonable R-squares ranging from 37 to 53 per cent.

We now subject our results to robustness checks in Table 3, with more indicators on the host country's labor market regulation, a measure of its wage costs and the inclusion of time trends. Other controls from Table 2 are included in the specifications, but are not shown. The wage cost per hour for a tool-maker, added in the first column, has no significant impact on the employment. The coefficient of EPL remains negative and significant. In column 4, we add the knock-on cost of regulation in non-manufacturing industries which act as inputs in manufacturing industries, the coefficient of which is negative but not significant, while the impact of EPL remains robust. This is the case also when we add the other measures for labor market institutions and intellectual property rights one by one in columns 2-7, and all of these controls in column 8. Here, wage costs and bargaining centralization have a significantly negative and positive impact, respectively, on log employment (the latter result consistent with the literature on centralization of wage bargaining, see Driffill, 2006). The coefficients of EPL are quite robust across these specifications in Table 3, ranging from -0.136 to -0.178 , which supports our hypothesis that the employment level of Swedish foreign affiliates is negatively associated with strong EPL of the host country.

10 See Norbäck (2001). 
In columns 9-11 of Table 3, we experiment with a time trend and country-specific trends, entered linearly and applied to the specifications of Table 2. The coefficient on the EPL variable remains negative in all three specifications, but retains significance only in the estimation with firm fixed effects (column 10). Considering the evolution of EPL, depicted in Figure 1, the inclusion of country-specific trends may take away too much of the variation in this variable. It is also possible that some unobserved variable, correlated with EPL, drives the results. We discuss this further in Section 4.3.3. Our experiments with excluding countries with small GDP per capita (Greece, Portugal and Spain) did not produce substantial changes in the results, suggesting that endogeniety in this respect is not a serious problem in the analysis. ${ }^{11}$

In Table 4, we include EPL in neighboring countries among the explanatory variables. The effect is negative, but insignificant in most cases. This may be due to the fact that we do not know which countries affiliates export to or from which countries import competition occurs, resulting in too imprecise a measure. ${ }^{12}$

In Table 5, we finally examine whether the effects of EPL are heterogeneous across industries. Firms which are active in industries with high volatility in employment seem to reduce employment when EPL is increasing, as revealed by results for the interacted variable. (Volatility could not be included as a separate variable, due to industry fixed effects.) However, large firms (with above median size) turn out to be more sensitive than smaller firms to increasing stringency of EPL. The latter result can be explained from the theory in the sense that larger firms (from higher consumer willingness to pay) face higher direct costs from EPL. More generally, it suggests that larger firms may be more footloose than smaller ones, presumably as the former have more locations to choose among.

\footnotetext{
${ }^{11}$ The results are not shown but available from the authors on request.

${ }^{12}$ Olney (2012) reports that the stringency of EPL in a host country is significantly correlated with a weighted average of EPL in neighboring countries. This is consistent with the theory presented in our paper where EPL affects production costs. The reason is that host countries should then internalize the effect of more stringent EPL on the host country's competitiveness. While consistent with theory this makes identification of this "race to the bottom" competition in EPL cumbersome.
} 


\subsubsection{The composition of affiliate sales into local sales and exports}

The results in Tables 2-5 indicate that more stringent EPL increases wage costs which reduce affiliate total employment. While the estimates tell us that total employment $l_{S}^{*}(\theta)$ is decreasing in stricter EPL, $f_{S}$, they do not give information if the negative effect on employment is generated in production for exports or in production for local sales. In Table 6 , we therefore explore the composition of sales divided into total sales, local sales, total exports and exports to third country. In column 1, where total sales is the dependent variable, EPL has a significantly negative effect. This is true also for exports (column 3) and exports to third country (column 4), but not for local sales (column 2). The estimated coefficient for export to third countries is -0.266 , which corresponds to a 30 per cent decrease in export sales.

We can then state the following result:

Result 1: The estimates in Tables 2 and 5 show that when EPL becomes more stringent; ( $i$ ) affiliate employment is reduced, $\hat{l}_{S}^{*}(\theta)<0$, (ii) export sales decrease, $\hat{R}_{S R}^{*}(\theta)<0$, while (iii) local sales are unaffected, $\hat{R}_{S S}^{*}(\theta)=0$. From Proposition 1, this is consistent with stronger $E P L$ in country $S$ leading to increased wage costs, $\varphi_{f}^{\prime}\left(f_{S}\right)>0$, resulting in lower employment in both affiliate activities production for exports and local sales, $\hat{l}_{S R}^{*}(\theta)<0$ and $\hat{l}_{S S}^{*}(\theta)<0$.

To see why the estimates are consistent with more stringent EPL increasing wage costs, first consider the estimate in $(21)$ for local sales, $\hat{\beta}_{f_{S}}=0$. From equation (15) this implies that $\hat{R}_{S S}^{*}(\theta)=0 .{ }^{13}$ From (15) it then follows that $\frac{w_{S}}{\delta(\theta)}=\frac{\sum_{-} \theta \mid S\left(\frac{w_{S}}{\delta(-\theta)}\right)}{n_{S}} \frac{\varsigma_{S S}(\theta)}{\eta_{S S}(\theta)}$. Since $\varsigma_{S j}(\theta) / \eta_{S j}(\theta)>$ 1 , it then follows from $(12)$ that $\hat{l}_{S S}^{*}(\theta)<0$. Intuitively, if more stringent EPL increases wage costs, the marginal cost of firms producing in country $S$ must increase which from (14) implies that the affiliate must increase its product market price, $\hat{P}_{S}^{*}(\theta)>0$. But then since there is no change in affiliate local sales at an increasing marginal cost, $\hat{R}_{S S}^{*}(\theta)=\hat{P}_{S}^{*}(\theta)+$ $\hat{l}_{S S}^{*}(\theta)=0$, the increase in product market price $\hat{P}_{S}^{*}(\theta)>0$ fully compensates for the

${ }^{13}$ Equation (15) can be rewritten as $\hat{\beta}_{f_{S}}=E l_{f_{S}} R_{S j}^{*}=\eta_{S j}(\theta)\left[\frac{\sum_{-\theta \mid S\left(\frac{w_{S}}{\delta(-\theta)}\right)}}{n_{j}} \frac{S_{S j}(\theta)}{\eta_{S j}(\theta)}-\frac{w_{S}}{\delta(\theta)}\right] \frac{n_{j} \sigma_{j}}{n_{j}+1} f_{S} \varphi^{\prime}\left(f_{S}\right), \quad j=$ $\{S, R\}$. 
reduction in employment, $\hat{l}_{S S}^{*}(\theta)<0$. Thus, the fact that local sales do not change is consistent with a lower employment in production for local sales arising from stricter EPL increasing wage costs. ${ }^{14}$

Let us then turn to the estimate for exports sales, $\hat{\beta}_{f_{S}}<0$. From (15) this implies $\hat{R}_{S R}^{*}(\theta)<0$ and hence that $\frac{w_{S}}{\delta(\theta)}>\frac{\Sigma_{-} \theta \mid S\left(\frac{w_{S}}{-\theta}\right)}{n_{R}} \frac{\varsigma_{S R}(\theta)}{\eta_{S R}(\theta)}$. Again noting that $\varsigma_{S R}(\theta) / \eta_{S R}(\theta)>1$, equation (12) implies that employment must be reduced, $\hat{l}_{S R}^{*}(\theta)<0$. Intuitively, as the price in the destination market in country $\mathrm{R}$ also increases as exporters from country $\mathrm{S}$ see their marginal cost increase, $\hat{P}_{R}^{*}(\theta)>0$, employment in export sales must decrease $\hat{l}_{S R}^{*}(\theta)<0$, to generate a reduction of export sales, $\hat{R}_{S R}^{*}(\theta)=\hat{P}_{R}^{*}(\theta)+\hat{l}_{S R}^{*}(\theta)<0$. Thus, also employment for export production decreases from stricter EPL as wage costs increase.

In which activity, then, is employment reduced the most? The theory suggests that exports should be worse off since there will be many more competitors producing in export markets which do not incur higher wage costs from producing in the host country. We can use the change in employment in (11) to explore this potential asymmetry. Since $\hat{R}_{S S}^{*}(\theta)=0$, we have that $\hat{l}_{S S}^{*}(\theta)=-\hat{P}_{S}^{*}(\theta)$ from (13). We can then rewrite (11) as follows:

$$
\hat{l}_{S R}^{*}(\theta)=\frac{1}{1-\rho_{S S}(\theta)} \hat{l}_{S}^{*}(\theta)+\frac{\rho_{S S}(\theta)}{1-\rho_{S S}(\theta)} \hat{P}_{S}^{*}(\theta)
$$

Let us proxy employment shares with sales shares: on average 40 per cent of the affiliate sales are exported while the remaining 60 percent is sold locally. Substituting $\rho_{S S}=0.6$ from the data and calculating the reduction in total affiliate employment of $\hat{l}_{S}^{*}(\theta)=-0.15$ from an average of the estimates in Table 2, we can explore how affiliate employment reacts to a changing product market price in country $S, \hat{P}_{S}^{*}(\theta)$. For instance, suppose that stricter EPL leads to higher wage costs which in turn increase the product market price in country S by 10 percent. This will cause employment in local sales production to be reduced by 10 percent.

\footnotetext{
14 From (12) this will also imply that the affiliate faces an increase in its unit wage cost which is higher than the average increase in unit wage of its rivals. The intuition here is that even if the affiliate has a higher labor productivity than the average indigenous firm, and hence will be better off than the average indigenous rival when the cost of EPL increases, the affiliate faces stronger import competition from outside foreign rivals (who can produce at unchanged cost).
} 
From (22), however, this price increase will imply a reduction of employment in production for export sales with 22.5 percent, thus giving more than twice as large an effect on export employment.

Let us now use Equation (22) to illustrate why our estimates are not consistent with a setting where stricter EPL reduces the unit wage cost through, for instance, bonding (Lazear, 1990). To see this, suppose instead that stricter EPL would decrease wage costs, $\varphi_{f}^{\prime}\left(f_{S}\right)<0$. This could be consistent with unresponsive local sales, $\hat{R}_{S S}^{*}(\theta)=0$, if the implied reduction in product market price, $\hat{P}_{S}^{*}(\theta)<0$, generates an increase in affiliate employment for local sales, $\hat{l}_{S S}^{*}(\theta)>0$. However, to explain the reduction in total affiliate employment, $\hat{l}_{S}^{*}(\theta)<0$, found in our estimates, we would need an even stronger reduction in employment in export production. For instance, if we assume that more stringent EPL would decrease wage costs, with an associated fall in the product market price by 10 percent, equation (22) would imply a fall in export employment of 52.5 percent. But given the fact that wage costs fall when the MNE produces for export markets, this should give the MNE a competitive advantage over rivals and we should then observe that export sales increase - not decrease.

Robustness checks of the impact of exports to third countries are presented in Table 7. The table repeats the format of Table 3 , in which additional controls are successively added. Again, the coefficients of EPL do not change much across specifications when different indicators of regulation are included. However, the result that the coefficients are sensitive to the inclusion of time trends is repeated; the effects are positive, though never significant. Heterogeneity with respect to firm type is examined in Table 8 (in the same way as in Table 5). This exercise produces basically the same results as in Table 5 - volatility has a negative, but insignificant effect, and larger firms are more sensitive to more stringent EPL. Finally, we also examine the same specifications for local sales (not reported). Again, we do not find any qualitative change in results.

\subsubsection{The extensive margin of FDI}

Our findings, so far, that stricter EPL reduces employment and affiliate export sales, but not affiliate local sales, are consistent with stricter EPL increasing wage costs, $\varphi_{f}^{\prime}\left(f_{S}\right)>0$. We have also shown that these results are consistent with decreasing affiliate employment in 
production for local sales and exports when EPL becomes stricter. The latter implies that output in these activities also decreases which, in turn, implies that profits must decrease. Indeed, as shown in Proposition 2, the model then predicts that investment into a new affiliate FDI should be less likely when EPL becomes more stringent. In Table 9, we explore this prediction on the extensive margin of FDI by examining how the number of investments in new affiliates in a window, with two years before and two years after the survey year, is correlated with the Allard index of EPL in the survey. Table 9 shows the result from the negative binomial regression model. The table shows that the number of new affiliates is reduced when EPL becomes more stringent, as predicted by Proposition 2. The estimates have mostly good precision. As in the previous tables, the impact of most of the other labor market institutions seems to be small.

Result 2: The estimates in Table 9 show that when EPL becomes more stringent, the number of investments in new affiliates is reduced. From Proposition 2, this is consistent with stronger EPL in country $S$ leading to increased wage costs, $\varphi_{f}^{\prime}\left(f_{S}\right)>0$.

Overall, the estimates thus support the theory in which more stringent EPL increases firms' marginal costs. One caveat in this interpretation however arises from the estimates with country-specific trends. Comparing columns $11-12$ in Tables 3, 7 and 9 we note that a difference between the results on the extensive margin and the previous results on the intensive margin is that the former results regarding EPL are robust to the inclusion of country-specific time trends.

Finding that more stringent EPL has no effect on the intensive margin of FDI, but a negative effect on the extensive margin of FDI, could be argued to be consistent with MNEs adjusting their technology or capital structure when actual wage costs or expected wage costs increase. As discussed in the end of Section 3.1, if the MNEs make affiliates more cost-efficient when EPL becomes more stringent, the effect on employment and sales may be small. However, since the MNE will need to "overinvest" in capital or technology, the profitability of an investment will be reduced. In estimations, which are not displayed due to space constrains, we also found some evidence that more stringent EPL increases the capital labor ratio in the affiliates. We would still argue that the results are consistent with more stringent EPL increasing actual or expected wage costs. As discussed above, it may just be that the absence of effects of more stringent EPL on the intensive margin with country specific trends added simply reflects insufficient variation over time in EPL. 


\section{Discussion and conclusions}

In this paper, we have shown that stronger EPL in a host country has important effects on the activities of MNEs. Specifically, increased stringency in EPL is associated with less employment in affiliates and smaller sales in these firms. The various sales activities of the MNEs are not affected in the same way, however. We find that it is mainly exports that are affected negatively by stronger EPL, while the impact on local sales is small.

The heterogeneity in treatment effects of EPL across activities, which we established in the estimations, is in line with our theoretical model where increasing stringency of EPL contributes to higher wage costs. Since affiliates to MNEs are (typically) more productive than the average indigenous firm, and most firms active in the host country market are indigenous firms, a general wage cost increase may improve the competitive position of the MNE in the host country market, which mitigates the negative effect of a higher wage cost. However, since indigenous firms also constitute a majority of firms in the export destination and these firms are not directly affected by EPL in the host country, the affiliate will be less competitive in its export market. We also demonstrate that new investments by MNEs are deterred by stricter EPL. While our empirical results apply to Swedish MNEs, they should have wider significance since, typically, MNEs engage in both production for the country of location and exports.

It could be argued that our theoretical model is applicable to any regulation that drives up marginal cost. We do not present a story as to why adjustments to EPL, but not other types of regulation, are a driving force behind changes in FDI. However, we are not able to explain our empirical results with any other indicator of labor or product market regulation than EPL, so our focus on EPL in the theoretical analysis seems to be warranted by the data.

On a final note, despite the fact that we use a long observation period, with within-country variation in EPL, the variation in EPL is to a large extent correlated with country-specific trends. This makes it difficult to entirely rule out the possibility that underlying trends in unobserved country-specific variables, rather than changes in EPL, drive our results. A promising area for further research would be to exploit partial reforms within countries, especially those in which different regions or types of firms get differential treatment with respect to EPL (see Skedinger, 2010, for a survey of this literature). The variation in EPL thus generated could help identify its effects on FDI, since unobserved country-specific variables correlated with EPL are essentially controlled for in the partial-reform framework. 


\section{References}

Allard, G. 2005. Measuring Job Security over Time: In Search of a Historical Indicator for EPL (Employment Protection Legislation). Working Paper WP05-17, Instituto de Empresa, Madrid.

Céline A. and Desbordes R. 2010. Short-run Strategies for Attracting Foreign Direct Investment. The World Economy, 33(7), 928-957.

Barba Navaretti, G. and Venables, A.J. 2004. Multinational Firms in the World Economy (with F. Barry, K. Ekholm, A. Falzoni, J. Haaland, K.H. Midelfart and A. Turrini), Princeton, NJ: Princeton University Press.

Bassanini, A., Nunziata, L. and Venn, D. 2009. Job Protection Legislation and Productivity Growth in OECD Countries. Economic Policy, 24(58): 349-402.

Belot, M. and van Ours, J.C. 2004. Does the Recent Success of Some OECD Countries in Lowering Their Unemployment Rates Lie in the Clever Design of Their Labor Market Reforms? Oxford Economic Papers, 56(4): 621-642.

Benassy-Quéré, A., Coupet, M. and Mayer, T. 2007. Institutional Determinants of Foreign Direct Investment. World Economy, 30(5): 764-782.

Bertrand, O., Nilsson Hakkala, K., Norbäck, P.J. and Persson, L. 2012. Should Countries Block Foreign Takeovers of R\&D Champions and Promote Greenfield Entry. Canadian Journal of Economics , 45(3): 1083-1124.

Blanchard, O. and Wolfers, J. 2000. The Role of Shocks and Institutions in the Rise of European Unemployment: The Aggregate Evidence. Economic Journal, 110(462): C1-C33.

Braconier, H, Norbäck, P.J., and Urban, D. 2005a. Multinational Enterprises and Wage Costs: Vertical FDI Revisited. Journal of International Economics, 67(2): 446-470. 
Braconier, H., Norbäck, P.J. and Urban, D. 2005b. Reconciling the Evidence of the Knowledge Capital Model. Review of International Economics, 13(4): 770-786.

Davies, R.B., Tekin-Koru, A. and Norbäck, P.J. 2009. The Effect of Tax Treaties on Multinational Firms: New Evidence from Microdata. World Economy, 32(1): 77-110.

Dewit, G. Görg, H. and Montagna, C. 2007. Shall I Stay or Shall I Go? Foreign Direct Investment, Employment Protection, and Domestic Anchorage. Review of World Economics, 145(1): 93-110.

Driffill, J. 2006. The Centralization of Wage Bargaining Revisited: What Have We Learnt? Journal of Common Market Studies, 44(4): 731-756.

Ginarte, J. and Park, W. 1997. "Intellectual Property Rights and Economic Growth", Contemporary Economic Policy, 15(3), pp. 51-61.

Görg, H. 2005. Fancy a Stay at the Hotel California? Foreign Direct Investment, Taxation and Firing Costs. Kyklos, 58(4): 519-535

Greenaway, D. and Nelson, D. 2001. The Assessment: Globalization and Labor-Market Adjustment. Oxford Review of Economic Policy, 16(3): 1-11.

Gross, D.M. and Ryan, M. 2008. FDI Location and Size: Does Employment Protection Legislation Matter? Regional Science and Urban Economics, 38(6): 590-605.

Haaland, J., Wooton, I. and Faggio, G. 2002. Multinational Firms: Easy Come, Easy Go? FinanzArchiv, 2002-2003, 59(1): 3-26.

Hakkala, K., Norbäck, P.J. and Svaleryd, H. 2008. Asymmetric Effects of Corruption on FDI: Evidence from Swedish Multinational Firms. Review of Economics and Statistics, 90(4): $627-642$.

Harris, C. 1954. The Market Factor in the Localization of Industry in the United States. Annals of the Association of American Geographers, 44(4): 315-348. 
Helpman. E. 2006. Trade, FDI, and Organization of Firms. Journal of Economic Literature, 44(4): 589-630.

Howell, D., Baker, D., Glyn, A. and Schmitt, J. 2007. Are Protective Labor Market Institutions at the Root of Unemployment? A Critical Review of the Evidence. Capitalism and Society, 2(1): article 1.

Javorcik, B. and Spatareanu, M 2005. Do Foreign Investors Care About Labor Market Regulations? Review of World Economics, 141(3): 375-403.

Koeniger, W. 2005. Dismissal Costs and Innovation. Economics Letters, 88(1): 79-84.

Lafontaine, F. and Sivadasan, J. 2009. Do Labor Market Rigidities Have Microeconomic Effects? Evidence from within the Firm. American Economic Journal: Applied Economics, 1(2): $88-127$.

Lazear, E. 1990, Job Security Provisions and Employment. Quarterly Journal of Economics, 105(3): 699-726.

Leahy, D., and Montagna, C. 2000. Unionisation and Foreign Direct Investment: Challenging Conventional Wisdom? Economic Journal, 110(462): C80-C92.

Nickel. W. 2006. The CEP-OECD Institutions Data Set (1960-2004). CEP Discussion Paper No 759, November 2006

Norbäck, P.J. 2001. Multinational Firms, Technology and Location. Journal of International Economics, 54(2): 449-469

OECD (2004), Employment Outlook. Paris.

Olney, W. 2012. A Race to the Bottom? Employment Protection and Foreign Direct Investment. Mimeo. Department of Economics, Williams College, Williamstown, MA. 
Skedinger, P. 2010. Employment Protection Legislation. Evolution, Effects, Winners and Losers. Edward Elgar, Cheltenham, UK, and Northampton, MA, USA.

Swedenborg, B. 1979. The multinational operations of Swedish firms: an analysis of determinants and effects. Stockholm: Industrial inst. for economic and social research (Industriens utredningsinstitut). 
Figure 1: The structure of the model.

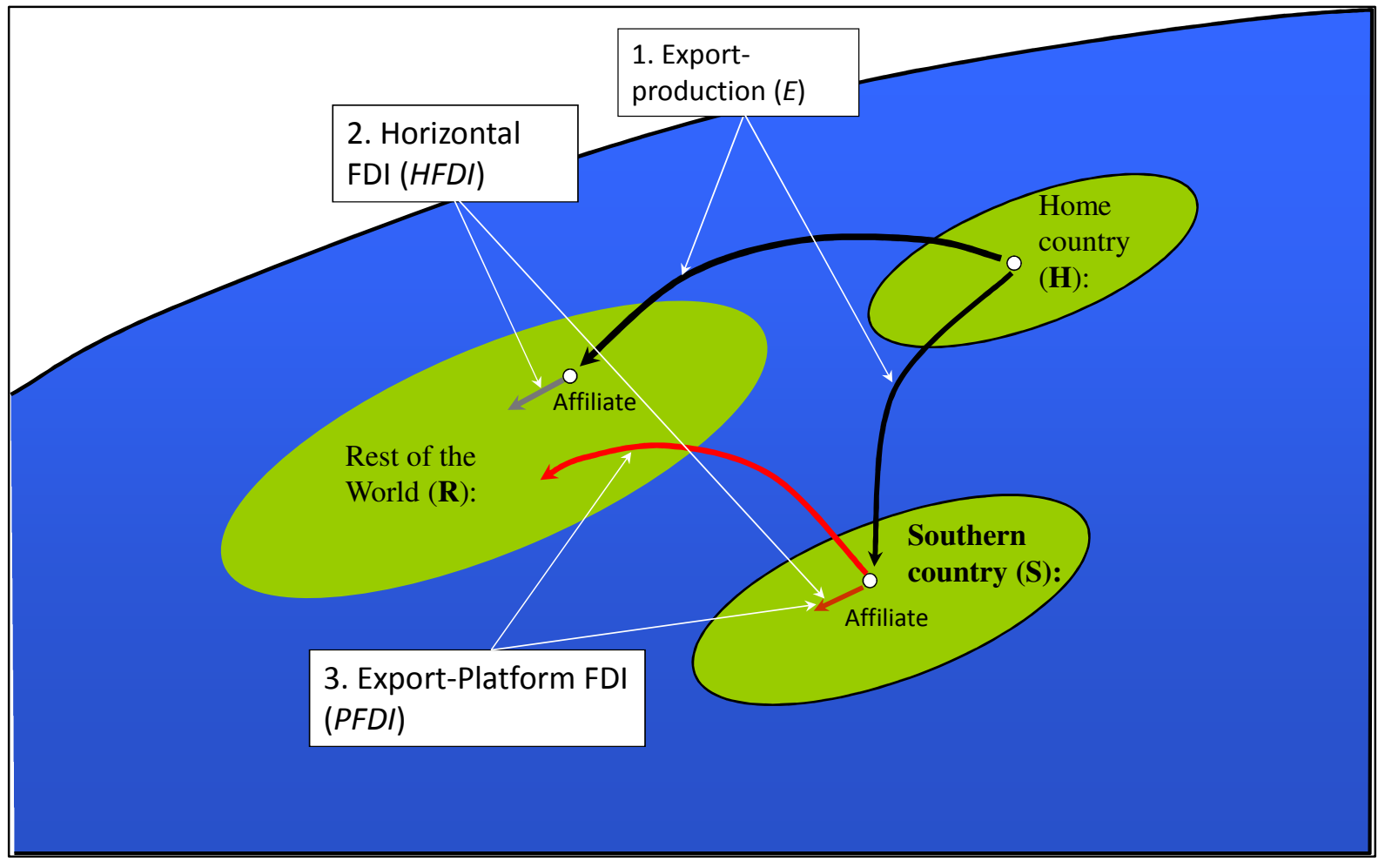


Figure 2: Average affiliate log employment by year and country.

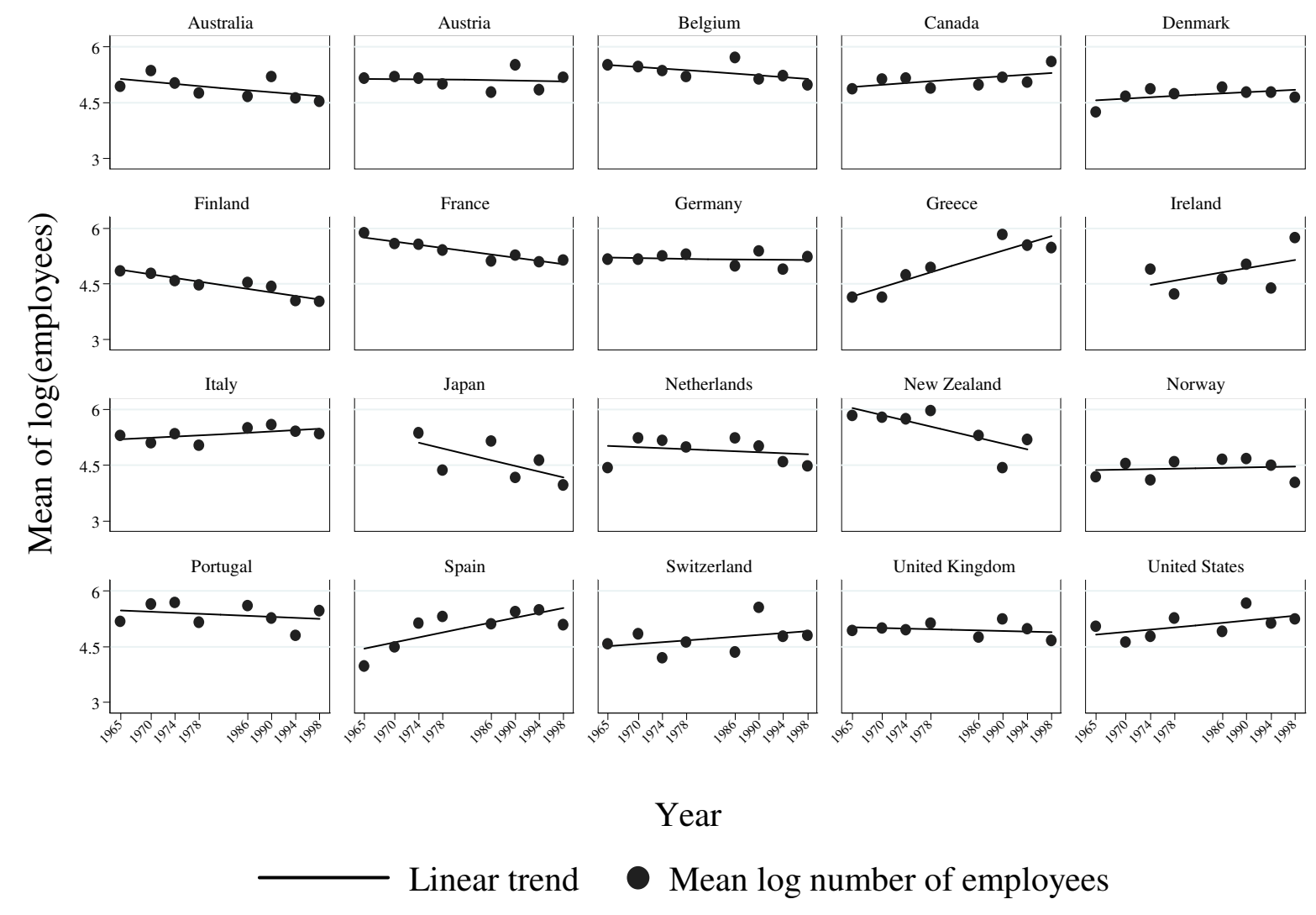


Figure 3: Average (log) affiliate export sales and affiliate local sales by year and country.

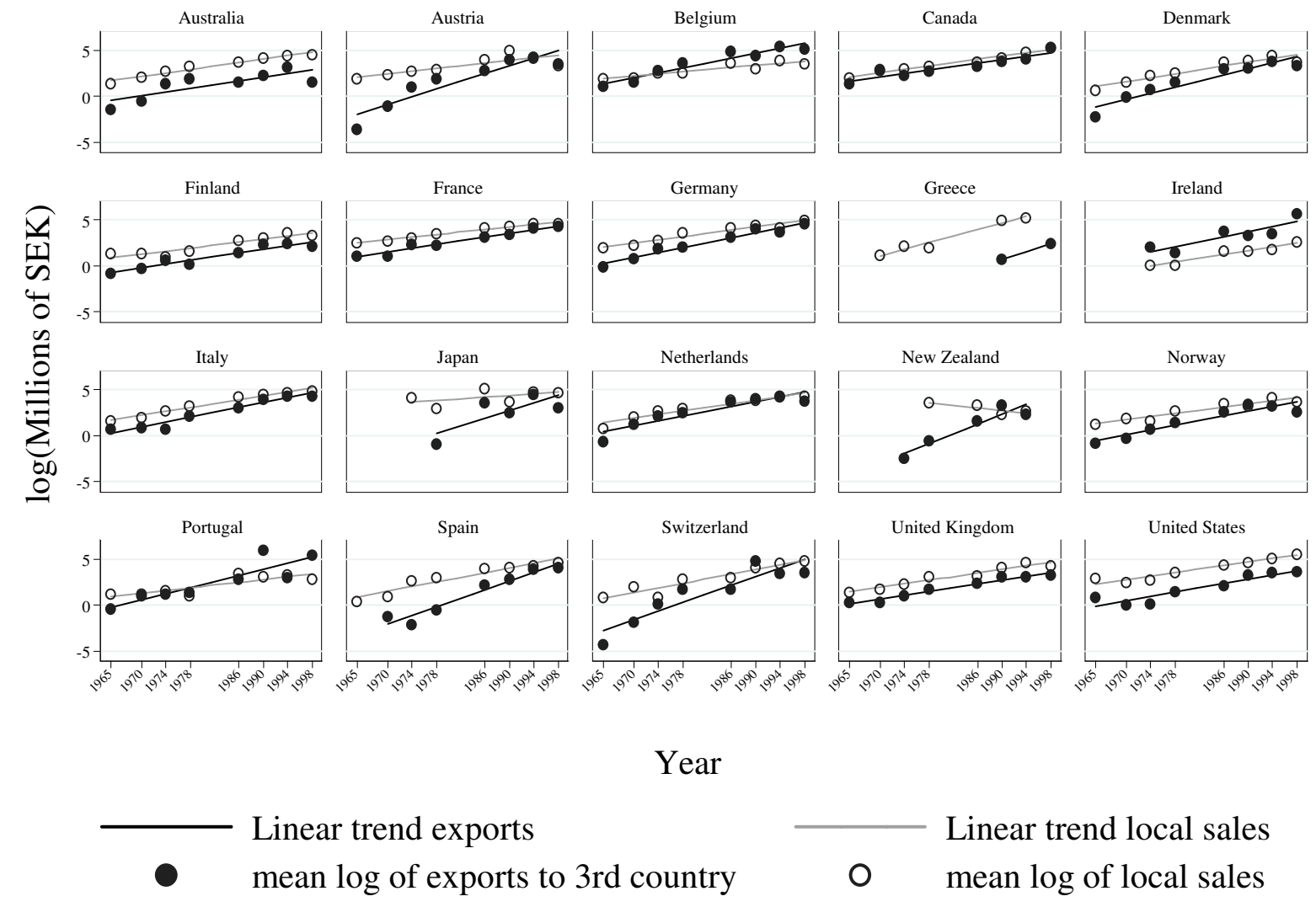


Figure 4: Allard's EPL index by year and country.

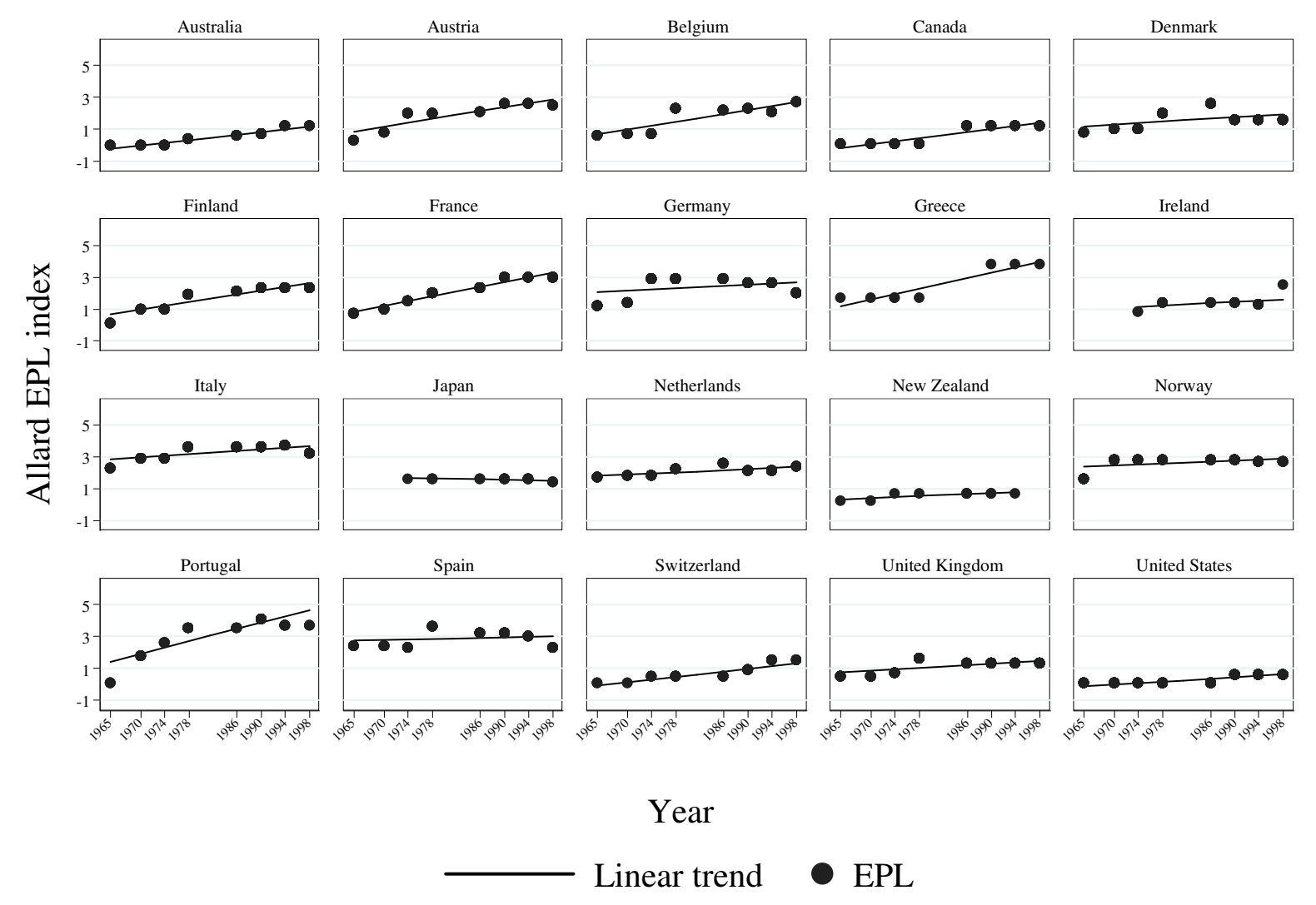




\begin{tabular}{|c|c|c|c|c|c|}
\hline VARIABLES & Mean & $\mathrm{Sd}$ & Min & Max & $\mathrm{N}$ \\
\hline Log number of employees & 5.025 & 1.433 & 0 & 9.800 & 3,606 \\
\hline EPL & 1.816 & 1.006 & 0 & 4.100 & 3,619 \\
\hline Real GDP (distance weighted) & 8.775 & 0.636 & 6.396 & 9.896 & 3,619 \\
\hline Economic Openness & 3.735 & 0.506 & 2.222 & 5.146 & 3,580 \\
\hline Host Real GDP & 20.07 & 1.432 & 17.06 & 22.85 & 3,580 \\
\hline Host Real GDP per capita & 9.777 & 0.288 & 8.423 & 10.34 & 3,580 \\
\hline Parent size & 8.336 & 2.274 & 1.160 & 12.31 & 3,615 \\
\hline Parent R\&D intensity & -4.372 & 1.504 & -9.210 & -1.354 & 3,486 \\
\hline Experience & 0.961 & 0.193 & 0 & 1 & 3,619 \\
\hline Age of affiliate & 13.22 & 16.01 & 0 & 103 & 3,430 \\
\hline Initial sales of affiliate & 0.142 & 0.349 & 0 & 1 & 3,423 \\
\hline EU & 0.597 & 0.491 & 0 & 1 & 3,619 \\
\hline NAFTA & 0.0829 & 0.276 & 0 & 1 & 3,619 \\
\hline Log of wage cost per hour for a toolmaker (UBS) & 2.882 & 0.417 & 1.274 & 3.658 & 3,014 \\
\hline Regulation impact & 0.104 & 0.0347 & 0.0305 & 0.242 & 2,954 \\
\hline Union coverage & 69.26 & 25.30 & 15 & 99 & 3,295 \\
\hline Union density & 38.16 & 18.65 & 8.600 & 78 & 3,503 \\
\hline Bargaining centralization & 1.950 & 0.629 & 1 & 3 & 3,611 \\
\hline Gross benefit replacement rates & 41.56 & 19.26 & 0 & 80.30 & 3,611 \\
\hline Intellectual property rights & 3.644 & 0.615 & 1.980 & 4.860 & 3,619 \\
\hline Log of sales & 4.365 & 1.833 & -2.688 & 9.984 & 3,609 \\
\hline Log of assembly & 3.903 & 1.880 & -2.882 & 9.984 & 3,162 \\
\hline Log of direct sales & 2.755 & 2.208 & -5.298 & 8.816 & 1,805 \\
\hline Log of local sales & 3.480 & 1.936 & -6.215 & 9.869 & 2,862 \\
\hline Log of exports & 2.804 & 2.302 & -6.215 & 9.956 & 2,745 \\
\hline Log of exports to 3rd country & 2.660 & 2.415 & -6.908 & 9.260 & 2,490 \\
\hline Log of exports to Sweden & 1.160 & 2.207 & -6.908 & 9.957 & 1,849 \\
\hline Firm is larger than median & 0.397 & 0.489 & 0 & 1 & 3,619 \\
\hline Firm is in sector with high volatility in sales & 0.586 & 0.493 & 0 & 1 & 3,619 \\
\hline
\end{tabular}




\begin{tabular}{|c|c|c|c|}
\hline VARIABLES & $\begin{array}{c}(1) \\
\text { Base } \\
\end{array}$ & $\begin{array}{c}(2) \\
\text { Firm FE } \\
\end{array}$ & $\begin{array}{c}\text { (3) } \\
\text { Ind. FE }\end{array}$ \\
\hline EPL & $\begin{array}{c}-0.176 * * * \\
(-3.282)\end{array}$ & $\begin{array}{l}-0.118 * * \\
(-2.638)\end{array}$ & $\begin{array}{c}-0.161 * * * \\
(-3.566)\end{array}$ \\
\hline Real GDP (distance weighted) & $\begin{array}{c}-0.202 \\
(-0.604)\end{array}$ & $\begin{array}{c}-0.190 \\
(-0.733)\end{array}$ & $\begin{array}{l}0.0883 \\
(0.292)\end{array}$ \\
\hline Economic Openness & $\begin{array}{l}-0.0706 \\
(-0.213)\end{array}$ & $\begin{array}{c}-0.211 \\
(-0.945)\end{array}$ & $\begin{array}{l}-0.0249 \\
(-0.137)\end{array}$ \\
\hline Host Real GDP & $\begin{array}{l}-0.0741 \\
(-0.112)\end{array}$ & $\begin{array}{c}0.406 \\
(0.555)\end{array}$ & $\begin{array}{c}0.258 \\
(0.468)\end{array}$ \\
\hline Host Real GDP per capita & $\begin{array}{c}0.546 \\
(0.721)\end{array}$ & $\begin{array}{c}0.117 \\
(0.138)\end{array}$ & $\begin{array}{c}0.152 \\
(0.293)\end{array}$ \\
\hline Parent size & $\begin{array}{c}0.364 * * * \\
(24.91)\end{array}$ & $\begin{array}{c}0.479 * * * \\
(6.340)\end{array}$ & $\begin{array}{c}0.335 * * * \\
(21.14)\end{array}$ \\
\hline Parent R\&D intensity & $\begin{array}{c}-0.0460 * * \\
(-2.372)\end{array}$ & $\begin{array}{l}0.0226 \\
(0.908)\end{array}$ & $\begin{array}{l}-0.0122 \\
(-0.863)\end{array}$ \\
\hline Experience & $\begin{array}{c}0.188 * * \\
(2.324)\end{array}$ & $\begin{array}{c}0.395 * * * \\
(2.999)\end{array}$ & $\begin{array}{l}0.139 * \\
(1.843)\end{array}$ \\
\hline Age of affiliate & $\begin{array}{c}0.0235 * * * \\
(12.62)\end{array}$ & $\begin{array}{c}0.0242 * * * \\
(13.44)\end{array}$ & $\begin{array}{c}0.0214 * * * \\
(9.402)\end{array}$ \\
\hline Initial sales of affiliate & $\begin{array}{l}0.0838 \\
(1.182)\end{array}$ & $\begin{array}{c}0.225 * * \\
(2.565)\end{array}$ & $\begin{array}{c}0.190 * * * \\
(3.607)\end{array}$ \\
\hline EU & $\begin{array}{c}0.213 * * \\
(2.644)\end{array}$ & $\begin{array}{c}0.291 * * * \\
(3.439)\end{array}$ & $\begin{array}{c}0.333^{* * *} * \\
(5.366)\end{array}$ \\
\hline NAFTA & $\begin{array}{c}0.374 * * * \\
(3.883)\end{array}$ & $\begin{array}{c}0.265 * * \\
(2.389)\end{array}$ & $\begin{array}{c}0.367 * * * \\
(5.643)\end{array}$ \\
\hline Constant & $\begin{array}{c}-0.334 \\
(-0.0361)\end{array}$ & $\begin{array}{c}-6.731 \\
(-0.761)\end{array}$ & $\begin{array}{c}-6.204 \\
(-0.914)\end{array}$ \\
\hline $\begin{array}{l}\text { Observations } \\
\text { R-squared }\end{array}$ & $\begin{array}{l}3,242 \\
0.365\end{array}$ & $\begin{array}{l}3,242 \\
0.522\end{array}$ & $\begin{array}{l}3,242 \\
0.528\end{array}$ \\
\hline $\begin{array}{l}\text { Year FE } \\
\text { Firm FE } \\
\text { Industry FE } \\
\text { Time trend } \\
\text { Country trends }\end{array}$ & $\begin{array}{l}\text { Yes } \\
\text { No } \\
\text { No } \\
\text { No } \\
\text { No }\end{array}$ & $\begin{array}{l}\text { Yes } \\
\text { Yes } \\
\text { No } \\
\text { No } \\
\text { No }\end{array}$ & $\begin{array}{l}\text { Yes } \\
\text { No } \\
\text { Yes } \\
\text { No } \\
\text { No }\end{array}$ \\
\hline
\end{tabular}


Table 3: Log number of employees, robustness checks

\begin{tabular}{|c|c|c|c|c|c|c|c|c|c|c|c|}
\hline VARIABLES & $\begin{array}{l}(1) \\
\text { UBS }\end{array}$ & $\begin{array}{c}\text { (2) } \\
\text { Regulation }\end{array}$ & $\begin{array}{c}\text { (3) } \\
\text { Union coverage }\end{array}$ & $\begin{array}{c}\text { (4) } \\
\text { Union density }\end{array}$ & $\begin{array}{c}\text { (5) } \\
\text { Bargaining } \\
\text { coverage }\end{array}$ & $\begin{array}{c}(6) \\
\text { Replacement } \\
\text { rates } \\
\end{array}$ & $\begin{array}{c}(7) \\
\text { Property } \\
\text { rights } \\
\end{array}$ & $\begin{array}{l}\text { (8) } \\
\text { All }\end{array}$ & $\begin{array}{c}(9) \\
\text { Base + } \\
\text { trends } \\
\end{array}$ & $\begin{array}{c}(10) \\
\text { Firm FE } \\
+ \text { trends } \\
\end{array}$ & $\begin{array}{c}(11) \\
\text { Ind. FE + } \\
\text { trends } \\
\end{array}$ \\
\hline EPL & $\begin{array}{c}-0.136 * * \\
(-2.281)\end{array}$ & $\begin{array}{c}-0.138 * * \\
(-2.198)\end{array}$ & $\begin{array}{c}-0.158 * * \\
(-2.529)\end{array}$ & $\begin{array}{c}-0.178 * * * \\
(-3.477)\end{array}$ & $\begin{array}{c}-0.163 * * * \\
(-3.826)\end{array}$ & $\begin{array}{c}-0.162 * * * \\
(-3.551)\end{array}$ & $\begin{array}{c}-0.165^{* * *} \\
(-3.627)\end{array}$ & $\begin{array}{c}-0.156^{* *} \\
(-2.224)\end{array}$ & $\begin{array}{l}-0.0794 \\
(-1.444)\end{array}$ & $\begin{array}{l}-0.118 * * \\
(-2.176)\end{array}$ & $\begin{array}{l}-0.0814 \\
(-1.203)\end{array}$ \\
\hline Log of wage cost per hour for a toolmaker (UBS) & $\begin{array}{c}-0.210 \\
(-1.254)\end{array}$ & & & & & & & $\begin{array}{c}-0.389 * * \\
(-2.592)\end{array}$ & & & \\
\hline Regulation impact & & $\begin{array}{c}-2.392 \\
(-0.878)\end{array}$ & & & & & & $\begin{array}{c}-3.236 \\
(-1.209)\end{array}$ & & & \\
\hline Union coverage & & & $\begin{array}{l}0.00294 \\
(0.629)\end{array}$ & & & & & $\begin{array}{c}-0.000221 \\
(-0.0465)\end{array}$ & & & \\
\hline Union density & & & & $\begin{array}{l}0.00136 \\
(0.505)\end{array}$ & & & & $\begin{array}{c}-0.000994 \\
(-0.182)\end{array}$ & & & \\
\hline Bargaining centralization & & & & & $\begin{array}{l}0.0448 \\
(0.690)\end{array}$ & & & $\begin{array}{c}0.273 * * * \\
(2.992)\end{array}$ & & & \\
\hline Gross benefit replacement rates & & & & & & $\begin{array}{c}0.000647 \\
(0.364)\end{array}$ & & $\begin{array}{l}-0.00421 \\
(-1.233)\end{array}$ & & & \\
\hline Intellectual property rights & & & & & & & $\begin{array}{l}0.0988 \\
(1.080)\end{array}$ & $\begin{array}{c}0.233 \\
(1.702)\end{array}$ & & & \\
\hline Constant & $\begin{array}{c}-3.369 \\
(-0.358)\end{array}$ & $\begin{array}{c}-4.952 \\
(-0.467)\end{array}$ & $\begin{array}{l}-2.920 \\
(-0.439)\end{array}$ & $\begin{array}{c}-5.658 \\
(-0.864)\end{array}$ & $\begin{array}{l}-5.629 \\
(-0.854)\end{array}$ & $\begin{array}{c}-5.138 \\
(-0.701)\end{array}$ & $\begin{array}{c}-6.129 \\
(-0.938)\end{array}$ & $\begin{array}{c}-4.840 \\
(-0.423)\end{array}$ & $\begin{array}{l}-44.37 \\
(-1.223)\end{array}$ & $\begin{array}{c}-53.33 * * \\
(-2.259)\end{array}$ & $\begin{array}{l}-26.28 \\
(-1.437)\end{array}$ \\
\hline Observations & 2,742 & 2,718 & 2,933 & 3,132 & 3,234 & 3,234 & 3,242 & 2,481 & 3,242 & 3,242 & 3,242 \\
\hline R-squared & 0.525 & 0.529 & 0.528 & 0.527 & 0.528 & 0.528 & 0.528 & 0.530 & 0.367 & 0.523 & 0.528 \\
\hline Year FE & Yes & Yes & Yes & Yes & Yes & Yes & Yes & Yes & No & No & No \\
\hline Firm FE & No & No & No & No & No & No & No & No & No & Yes & No \\
\hline Industry FE & Yes & Yes & Yes & Yes & Yes & Yes & Yes & Yes & No & No & Yes \\
\hline Time trend & No & No & No & No & No & No & No & No & Yes & Yes & Yes \\
\hline Country trends & No & No & No & No & No & No & No & No & Yes & Yes & Yes \\
\hline Other controls & Yes & Yes & Yes & Yes & Yes & Yes & Yes & Yes & Yes & Yes & Yes \\
\hline
\end{tabular}

*** $\mathrm{p}<0.01, * * \mathrm{p}<0.05, * \mathrm{p}<0.1$.

Notes: See notes to Table 2 . 
Table 4: Distance weighted EPL

\begin{tabular}{lcc}
\hline & \multicolumn{1}{c}{$(1)$} & $(2)$ \\
VARIABLES & Log no. of employees & Log exports to 3rd country \\
\hline EPL & $-0.156^{* * *}$ & $-0.260^{* *}$ \\
& $(-3.750)$ & $(-2.227)$ \\
EPL-weighted & -6.290 & -13.08 \\
& $(-1.425)$ & $(-0.986)$ \\
Constant & -2.499 & 1.310 \\
& $(-0.434)$ & $(0.0489)$ \\
& & \\
Observations & 3,242 & 2,238 \\
R-squared & 0.528 & 0.578 \\
& & \\
Year FE & Yes & Yes \\
Firm FE & No & No \\
Industry FE & Yes & Yes \\
Time trend & No & No \\
Country trends & No & No \\
Other controls & Yes & Yes \\
$* * *$ p $<0.01, * * \mathrm{p}<0.05, * \mathrm{p}<0.1$. & \\
Nos: &
\end{tabular}

Notes: See notes to Table 2. 
Table 5: Log number of employees, heterogeneity checks

\begin{tabular}{|c|c|c|c|}
\hline VARIABLES & $\begin{array}{c}\text { (1) } \\
\text { Volatile }\end{array}$ & $\begin{array}{c}(2) \\
\text { Large }\end{array}$ & $\begin{array}{c}(3) \\
\text { Volatile \& } \\
\text { large }\end{array}$ \\
\hline EPL & $\begin{array}{l}-0.128 * * \\
(-2.629)\end{array}$ & $\begin{array}{l}-0.101 * * \\
(-2.354)\end{array}$ & $\begin{array}{l}-0.0691 \\
(-1.442)\end{array}$ \\
\hline Firm is larger than median & & $\begin{array}{c}0.290 * * * \\
(3.409)\end{array}$ & $\begin{array}{c}0.286^{* * * *} \\
(3.400)\end{array}$ \\
\hline $\mathrm{EPL} *$ firm is larger than median & & $\begin{array}{c}-0.155 * * * \\
(-3.137)\end{array}$ & $\begin{array}{c}-0.155 * * * \\
(-3.130)\end{array}$ \\
\hline EPL $*$ firm is in sector with high volatility in sales & $\begin{array}{c}-0.0621 * * \\
(-2.145)\end{array}$ & & $\begin{array}{c}-0.0619 * \\
(-2.081)\end{array}$ \\
\hline Constant & $\begin{array}{c}-6.455 \\
(-0.942)\end{array}$ & $\begin{array}{c}-7.818 \\
(-1.191)\end{array}$ & $\begin{array}{c}-8.077 \\
(-1.215)\end{array}$ \\
\hline $\begin{array}{l}\text { Observations } \\
\text { R-squared }\end{array}$ & $\begin{array}{l}3,242 \\
0.528\end{array}$ & $\begin{array}{l}3,242 \\
0.530\end{array}$ & $\begin{array}{l}3,242 \\
0.531\end{array}$ \\
\hline $\begin{array}{l}\text { Year FE } \\
\text { Firm FE } \\
\text { Industry FE } \\
\text { Time trend } \\
\text { Country trends } \\
\text { Other controls }\end{array}$ & $\begin{array}{l}\text { Yes } \\
\text { No } \\
\text { Yes } \\
\text { No } \\
\text { No } \\
\text { Yes }\end{array}$ & $\begin{array}{l}\text { Yes } \\
\text { No } \\
\text { Yes } \\
\text { No } \\
\text { No } \\
\text { Yes }\end{array}$ & $\begin{array}{l}\text { Yes } \\
\text { No } \\
\text { Yes } \\
\text { No } \\
\text { No } \\
\text { Yes }\end{array}$ \\
\hline
\end{tabular}

*** $\mathrm{p}<0.01, * * \mathrm{p}<0.05, * \mathrm{p}<0.1$.

Notes: The variable 'Firm is in sector with high volatility in sales' is not included without the interaction, since it is captured by the industry FE. See also notes to Table 2. 
Table 6: Composition of sales

\begin{tabular}{|c|c|c|c|c|}
\hline VARIABLES & $\begin{array}{c}(1) \\
\text { Sales }\end{array}$ & $\begin{array}{c}\text { (2) } \\
\text { Local sales }\end{array}$ & $\begin{array}{c}(3) \\
\text { Exports }\end{array}$ & $\begin{array}{c}\text { (4) } \\
\text { Exports to 3rd country }\end{array}$ \\
\hline EPL & $\begin{array}{c}-0.109 * * * \\
(-3.555)\end{array}$ & $\begin{array}{l}-0.0805 \\
(-1.605)\end{array}$ & $\begin{array}{c}-0.235 * * * \\
(-2.884)\end{array}$ & $\begin{array}{c}-0.266 * * \\
(-2.377)\end{array}$ \\
\hline Age of affiliate & $\begin{array}{c}0.0233 * * * \\
(10.76)\end{array}$ & $\begin{array}{c}0.0175 * * * \\
(6.304)\end{array}$ & $\begin{array}{c}0.0145 * * * \\
(3.954)\end{array}$ & $\begin{array}{c}0.0109 * * \\
(2.759)\end{array}$ \\
\hline Real GDP (distance weighted) & $\begin{array}{c}0.409 \\
(1.396)\end{array}$ & $\begin{array}{l}0.976^{*} \\
(1.886)\end{array}$ & $\begin{array}{c}0.938 \\
(1.485)\end{array}$ & $\begin{array}{l}2.177 * \\
(2.049)\end{array}$ \\
\hline Economic Openness & $\begin{array}{c}0.519 * * \\
(2.466)\end{array}$ & $\begin{array}{l}0.462 * \\
(2.030)\end{array}$ & $\begin{array}{c}1.654 * * * \\
(3.993)\end{array}$ & $\begin{array}{c}2.364 * * * \\
(3.166)\end{array}$ \\
\hline Host Real GDP & $\begin{array}{c}0.0516 \\
(0.0829)\end{array}$ & $\begin{array}{c}-0.130 \\
(-0.154)\end{array}$ & $\begin{array}{c}-0.968 \\
(-1.013)\end{array}$ & $\begin{array}{l}-1.346 \\
(-1.039)\end{array}$ \\
\hline Host Real GDP per capita & $\begin{array}{c}0.503 \\
(0.778)\end{array}$ & $\begin{array}{c}0.415 \\
(0.537)\end{array}$ & $\begin{array}{c}0.676 \\
(0.567)\end{array}$ & $\begin{array}{c}1.337 \\
(0.864)\end{array}$ \\
\hline Parent size & $\begin{array}{c}0.363 * * * \\
(22.70)\end{array}$ & $\begin{array}{c}0.364 * * * \\
(16.81)\end{array}$ & $\begin{array}{c}0.344 * * * \\
(18.69)\end{array}$ & $\begin{array}{c}0.345^{* * * *} \\
(13.80)\end{array}$ \\
\hline Parent R\&D intensity & $\begin{array}{l}-0.0155 \\
(-0.950)\end{array}$ & $\begin{array}{c}-0.0863 * * \\
(-2.778)\end{array}$ & $\begin{array}{l}0.0293 \\
(0.841)\end{array}$ & $\begin{array}{c}0.00549 \\
(0.145)\end{array}$ \\
\hline Experience & $\begin{array}{c}0.338 * * * \\
(2.913)\end{array}$ & $\begin{array}{c}0.370 * * \\
(2.395)\end{array}$ & $\begin{array}{c}0.409 * * \\
(2.214)\end{array}$ & $\begin{array}{l}0.344^{*} \\
(2.041)\end{array}$ \\
\hline Initial sales of affiliate & $\begin{array}{c}0.467 * * * \\
(6.355)\end{array}$ & $\begin{array}{l}-0.0107 \\
(-0.117)\end{array}$ & $\begin{array}{l}-0.0288 \\
(-0.314)\end{array}$ & $\begin{array}{c}0.102 \\
(0.865)\end{array}$ \\
\hline EU & $\begin{array}{l}0.281 * * \\
(2.742)\end{array}$ & $\begin{array}{c}0.258 * * \\
(2.673)\end{array}$ & $\begin{array}{l}-0.0812 \\
(-0.408)\end{array}$ & $\begin{array}{l}0.0987 \\
(0.287)\end{array}$ \\
\hline NAFTA & $\begin{array}{l}0.00684 \\
(0.0692)\end{array}$ & $\begin{array}{c}0.116 \\
(1.519)\end{array}$ & $\begin{array}{c}0.218 \\
(1.372)\end{array}$ & $\begin{array}{c}0.0744 \\
(0.323)\end{array}$ \\
\hline Constant & $\begin{array}{c}-10.30 \\
(-1.025)\end{array}$ & $\begin{array}{c}-15.31 \\
(-1.378)\end{array}$ & $\begin{array}{c}-6.278 \\
(-0.542)\end{array}$ & $\begin{array}{c}-8.607 \\
(-0.364)\end{array}$ \\
\hline $\begin{array}{l}\text { Observations } \\
\text { R-squared }\end{array}$ & $\begin{array}{l}3,245 \\
0.703\end{array}$ & $\begin{array}{l}2,715 \\
0.665\end{array}$ & $\begin{array}{l}2,473 \\
0.592\end{array}$ & $\begin{array}{l}2,238 \\
0.578\end{array}$ \\
\hline $\begin{array}{l}\text { Year FE } \\
\text { Firm FE } \\
\text { Industry FE } \\
\text { Time trend } \\
\text { Country trends }\end{array}$ & $\begin{array}{l}\text { Yes } \\
\text { No } \\
\text { Yes } \\
\text { No } \\
\text { No }\end{array}$ & $\begin{array}{l}\text { Yes } \\
\text { No } \\
\text { Yes } \\
\text { No } \\
\text { No }\end{array}$ & $\begin{array}{l}\text { Yes } \\
\text { No } \\
\text { Yes } \\
\text { No } \\
\text { No }\end{array}$ & $\begin{array}{l}\text { Yes } \\
\text { No } \\
\text { Yes } \\
\text { No } \\
\text { No }\end{array}$ \\
\hline
\end{tabular}

Notes: See notes to Table 2. 
Table 7: Log exports to 3rd country, robustness checks

\begin{tabular}{|c|c|c|c|c|c|c|c|c|c|c|c|}
\hline VARIABLES & $\begin{array}{l}\text { (1) } \\
\text { UBS }\end{array}$ & $\begin{array}{c}\text { (2) } \\
\text { Regulation }\end{array}$ & $\begin{array}{c}(3) \\
\text { Union coverage }\end{array}$ & $\begin{array}{c}\text { (4) } \\
\text { Union density }\end{array}$ & $\begin{array}{c}5) \\
\text { Bargaining } \\
\text { centralization } \\
\end{array}$ & $\begin{array}{c}(6) \\
\begin{array}{c}\text { Replacement } \\
\text { rates }\end{array} \\
\end{array}$ & $\begin{array}{c}7) \\
\text { Property } \\
\text { rights } \\
\end{array}$ & $\begin{array}{l}\text { (8) } \\
\text { All }\end{array}$ & $\begin{array}{c}\text { (9) } \\
\text { Base + } \\
\text { trends } \\
\end{array}$ & $\begin{array}{c}10) \\
\text { Firm FE } \\
+ \text { trends } \\
\end{array}$ & $\begin{array}{c}(11) \\
\text { Ind. FE + } \\
\text { trends }\end{array}$ \\
\hline EPL & $\begin{array}{c}-0.314 * * * \\
(-2.953)\end{array}$ & $\begin{array}{c}-0.285^{* *} \\
(-2.619)\end{array}$ & $\begin{array}{c}-0.262 * * \\
(-2.558)\end{array}$ & $\begin{array}{c}-0.301 * * * \\
(-3.021)\end{array}$ & $\begin{array}{c}-0.260 * * \\
(-2.401)\end{array}$ & $\begin{array}{c}-0.277 * * \\
(-2.363)\end{array}$ & $\begin{array}{c}-0.267 * * \\
(-2.338)\end{array}$ & $\begin{array}{l}-0.251^{*} \\
(-1.925)\end{array}$ & $\begin{array}{c}0.163 \\
(1.672)\end{array}$ & $\begin{array}{l}0.0129 \\
(0.105)\end{array}$ & $\begin{array}{l}0.0585 \\
(0.645)\end{array}$ \\
\hline Log of wage cost per hour for a toolmaker (UBS) & $\begin{array}{c}-0.213 \\
(-0.860)\end{array}$ & & & & & & & $\begin{array}{c}-0.510 \\
(-1.646)\end{array}$ & & & \\
\hline Regulation impact & & $\begin{array}{c}1.586 \\
(0.264)\end{array}$ & & & & & & $\begin{array}{c}2.456 \\
(0.372)\end{array}$ & & & \\
\hline Union coverage & & & $\begin{array}{l}0.00111 \\
(0.115)\end{array}$ & & & & & $\begin{array}{l}-0.0179 \\
(-1.570)\end{array}$ & & & \\
\hline Union density & & & & $\begin{array}{c}0.00786 \\
(1.097)\end{array}$ & & & & $\begin{array}{c}0.0296^{* *} \\
(2.573)\end{array}$ & & & \\
\hline Bargaining centralization & & & & & $\begin{array}{c}-0.132 \\
(-0.911)\end{array}$ & & & $\begin{array}{l}0.315^{*} \\
(1.799)\end{array}$ & & & \\
\hline Gross benefit replacement rates & & & & & & $\begin{array}{c}0.00553 \\
(1.141)\end{array}$ & & $\begin{array}{c}-0.000941 \\
(-0.126)\end{array}$ & & & \\
\hline Intellectual property rights & & & & & & & $\begin{array}{l}0.0467 \\
(0.199)\end{array}$ & $\begin{array}{l}0.0766 \\
(0.255)\end{array}$ & & & \\
\hline Constant & $\begin{array}{l}20.43 \\
(0.680)\end{array}$ & $\begin{array}{l}20.06 \\
(0.598)\end{array}$ & $\begin{array}{c}7.799 \\
(0.427)\end{array}$ & $\begin{array}{c}-3.019 \\
(-0.171)\end{array}$ & $\begin{array}{c}-8.426 \\
(-0.339)\end{array}$ & $\begin{array}{c}-0.650 \\
(-0.0304)\end{array}$ & $\begin{array}{c}-8.467 \\
(-0.363)\end{array}$ & $\begin{array}{l}10.00 \\
(0.286)\end{array}$ & $\begin{array}{c}-31.32 \\
(-1.106)\end{array}$ & $\begin{array}{c}-42.89 \\
(-1.338)\end{array}$ & $\begin{array}{c}-5.153 \\
(-0.120)\end{array}$ \\
\hline Observations & 1,942 & 1,909 & 2,054 & 2,182 & 2,236 & 2,236 & 2,238 & 1,773 & 2,238 & 2,238 & 2,238 \\
\hline R-squared & 0.511 & 0.513 & 0.563 & 0.562 & 0.578 & 0.578 & 0.578 & 0.502 & 0.437 & 0.568 & 0.580 \\
\hline Year FE & Yes & Yes & Yes & Yes & Yes & Yes & Yes & Yes & No & No & No \\
\hline Firm FE & No & No & No & No & No & No & No & No & No & Yes & No \\
\hline Industry FE & Yes & Yes & Yes & Yes & Yes & Yes & Yes & Yes & No & No & Yes \\
\hline Time trend & No & No & No & No & No & No & No & No & Yes & Yes & Yes \\
\hline Country trends & No & No & No & No & No & No & No & No & Yes & Yes & Yes \\
\hline Other controls & Yes & Yes & Yes & Yes & Yes & Yes & Yes & Yes & Yes & Yes & Yes \\
\hline
\end{tabular}

Notes: See notes to Table 2 .
Not. 
Table 8: Log exports to 3rd country, heterogeneity checks

\begin{tabular}{|c|c|c|c|}
\hline VARIABLES & $\begin{array}{c}(1) \\
\text { Volatile }\end{array}$ & $\begin{array}{c}(2) \\
\text { Large }\end{array}$ & $\begin{array}{c}(3) \\
\text { Volatile \& } \\
\text { large }\end{array}$ \\
\hline EPL & $\begin{array}{c}-0.172 \\
(-1.595)\end{array}$ & $\begin{array}{c}-0.174 \\
(-1.382)\end{array}$ & $\begin{array}{l}-0.0841 \\
(-0.709)\end{array}$ \\
\hline Firm is larger than median & & $\begin{array}{c}0.431 * * \\
(2.751)\end{array}$ & $\begin{array}{c}0.420^{* *} \\
(2.721)\end{array}$ \\
\hline $\mathrm{EPL} *$ firm is larger than median & & $\begin{array}{c}-0.220 * * \\
(-2.773)\end{array}$ & $\begin{array}{c}-0.218 * * \\
(-2.678)\end{array}$ \\
\hline EPL $*$ firm is in sector with high volatility in sales & $\begin{array}{c}-0.161 \\
(-1.322)\end{array}$ & & $\begin{array}{c}-0.157 \\
(-1.254)\end{array}$ \\
\hline Constant & $\begin{array}{c}-10.93 \\
(-0.473)\end{array}$ & $\begin{array}{c}-20.49 \\
(-1.047)\end{array}$ & $\begin{array}{c}-15.89 \\
(-0.690)\end{array}$ \\
\hline $\begin{array}{l}\text { Observations } \\
\text { R-samared }\end{array}$ & $\begin{array}{l}2,238 \\
0,570\end{array}$ & $\begin{array}{l}2,238 \\
0,580\end{array}$ & $\begin{array}{l}2,238 \\
0,580\end{array}$ \\
\hline $\begin{array}{l}\text { Year FE } \\
\text { Firm FE } \\
\text { Industry FE } \\
\text { Time trend } \\
\text { Country trends } \\
\text { Other controls }\end{array}$ & $\begin{array}{l}\text { Yes } \\
\text { No } \\
\text { Yes } \\
\text { No } \\
\text { No } \\
\text { Yes }\end{array}$ & $\begin{array}{l}\text { Yes } \\
\text { No } \\
\text { Yes } \\
\text { No } \\
\text { No } \\
\text { Yes }\end{array}$ & $\begin{array}{l}\text { Yes } \\
\text { No } \\
\text { Yes } \\
\text { No } \\
\text { No } \\
\text { Yes }\end{array}$ \\
\hline
\end{tabular}

Notes: See notes to Table 5 . 
Table 9: Number of new investments

\begin{tabular}{|c|c|c|c|c|c|c|c|c|c|c|c|c|}
\hline VARIABLES & $\begin{array}{c}(1) \\
\text { Base }\end{array}$ & $\begin{array}{c}(2) \\
\text { Ind. FE }\end{array}$ & $\begin{array}{c}(3) \\
\text { UBS }\end{array}$ & $\begin{array}{c}(4) \\
\text { Regulation } \\
\text { impact }\end{array}$ & $\begin{array}{c}(5) \\
\text { Union } \\
\text { coverage }\end{array}$ & $\begin{array}{c}(6) \\
\text { Union } \\
\text { density }\end{array}$ & $\begin{array}{c}(7) \\
\text { Bargaining } \\
\text { centralization }\end{array}$ & $\begin{array}{l}(8) \\
\text { Replacement } \\
\text { rates }\end{array}$ & $\begin{array}{l}(9) \\
\text { Property } \\
\text { rights }\end{array}$ & $\begin{array}{l}(10) \\
\text { All } \\
\end{array}$ & $\begin{array}{l}(11) \\
\text { Base + } \\
\text { trends }\end{array}$ & $\begin{array}{c}(12) \\
\text { Ind. FE + } \\
\text { trends }\end{array}$ \\
\hline EPL & $\begin{array}{c}-0.184 * * \\
(-2.321)\end{array}$ & $\begin{array}{c}-0.191 * * \\
(-2.316)\end{array}$ & $\begin{array}{c}-0.119 \\
(-1.224)\end{array}$ & $\begin{array}{l}-0.108 \\
(-1.064)\end{array}$ & $\begin{array}{l}-0.174 * \\
(-1.897)\end{array}$ & $\begin{array}{c}-0.251 * * \\
(-2.530)\end{array}$ & $\begin{array}{c}-0.209 * * * \\
(-2.840)\end{array}$ & $\begin{array}{c}-0.178^{* *} \\
(-2.191)\end{array}$ & $\begin{array}{c}-0.200 * * \\
(-2.485)\end{array}$ & $\begin{array}{c}-0.125 \\
(-1.292)\end{array}$ & $\begin{array}{l}-0.113 * \\
(-1.748)\end{array}$ & $\begin{array}{c}-0.166^{* *} \\
(-2.297)\end{array}$ \\
\hline Log of wage cost per hour for a toolmaker (UBS) & & & $\begin{array}{l}-0.0713 \\
(-0.170)\end{array}$ & & & & & & & $\begin{array}{c}-0.315 \\
(-0.776)\end{array}$ & & \\
\hline Regulation impact & & & & $\begin{array}{c}-0.617 \\
(-0.234)\end{array}$ & & & & & & $\begin{array}{c}-3.702 \\
(-1.303)\end{array}$ & & \\
\hline Union coverage & & & & & $\begin{array}{c}0.00635 \\
(0.864)\end{array}$ & & & & & $\begin{array}{l}-0.00672 \\
(-1.012)\end{array}$ & & \\
\hline Union density & & & & & & $\begin{array}{c}0.0158 * * \\
(2.143)\end{array}$ & & & & $\begin{array}{c}0.00899 \\
(0.911)\end{array}$ & & \\
\hline Bargaining centralization & & & & & & & $\begin{array}{c}0.525 * * * \\
(4.252)\end{array}$ & & & $\begin{array}{c}0.647 * * \\
(2.558)\end{array}$ & & \\
\hline Gross benefit replacement rates & & & & & & & & $\begin{array}{c}-0.00104 \\
(-0.278)\end{array}$ & & $\begin{array}{l}-0.0108 \\
(-1.625)\end{array}$ & & \\
\hline Intellectual property rights & & & & & & & & & $\begin{array}{c}0.170 \\
(0.590)\end{array}$ & $\begin{array}{c}0.279 \\
(1.067)\end{array}$ & & \\
\hline Constant & $\begin{array}{c}12.70 \\
(0.995)\end{array}$ & $\begin{array}{c}15.84 \\
(1.218)\end{array}$ & $\begin{array}{c}8.822 \\
(0.365)\end{array}$ & $\begin{array}{c}8.997 \\
(0.330)\end{array}$ & $\begin{array}{c}4.847 \\
(0.301)\end{array}$ & $\begin{array}{c}8.256 \\
(0.594)\end{array}$ & $\begin{array}{l}22.94 * * \\
(2.137)\end{array}$ & $\begin{array}{c}15.59 \\
(1.062)\end{array}$ & $\begin{array}{c}15.37 \\
(1.201)\end{array}$ & $\begin{array}{c}-8.889 \\
(-0.481)\end{array}$ & $\begin{array}{c}44.47 \\
(1.386)\end{array}$ & $\begin{array}{c}31.30 \\
(0.963)\end{array}$ \\
\hline Observations & 16,414 & 16,414 & 12,482 & 12,595 & 12,183 & 14,397 & 15,590 & 15,590 & 16,414 & 9,436 & 16,414 & 16,414 \\
\hline Year FE & Yes & Yes & Yes & Yes & Yes & Yes & Yes & Yes & Yes & Yes & No & No \\
\hline Firm FE & No & No & No & No & No & No & No & No & No & No & No & No \\
\hline Industry FE & No & Yes & Yes & Yes & Yes & Yes & Yes & Yes & Yes & Yes & No & Yes \\
\hline Time trend & No & No & No & No & No & No & No & No & No & No & Yes & Yes \\
\hline Country trends & No & No & No & No & No & No & No & No & No & No & Yes & Yes \\
\hline Other controls & Yes & Yes & Yes & Yes & Yes & Yes & Yes & Yes & Yes & Yes & Yes & Yes \\
\hline
\end{tabular}

Notes: The specifications estimate a negative binomial regression model where the dependent variable is the number of new affiliates in a window two years before and two years after a survey. Unlike Tables $2-8$, Notes: The specifications estimate a negative binomial regression model where the dependent variable is
industry FE refer to the industry of the parent (not the industry of the affiliate). See also notes to Table 2. 